\title{
ARTYKUŁY
}

http://dx.doi.org/10.15762/ZH.2018.02

KAROL ŁOPATECKI

(Uniwersytet $w$ Białymstoku)

\section{Wyprawa zbrojna Krzysztofa RadziwiŁŁA „Pioruna” W INFLANTACH ZIMĄ 1579 ROKU $^{*}$}

Słowa kluczowe: itinerarium, kartografia wojskowa, Kierepeć, Dorpat, Inflanty XVI w.

W artykule prezentuję wyprawę Krzysztofa „Pioruna” Radziwiłła na Dorpat (Tartu) przeprowadzoną zimą 1579 r. Zagadnienie to doczekało się krótkiego omówienia w literaturze przedmiotu ${ }^{1}$. Chciałbym jednak wyprawę tę przeanalizować, wykorzystując nieznane badaczom itinerarium ${ }^{2}$. Źródło to zmienia całkowicie nasze wyobrażenie o tej konfrontacji, ukazuje umiejętność wykorzystania sztuki manewrowej, czyli praktyczną zdolność do przeprowadzenia skomplikowanych działań operacyjnych, a także strategicznych. Z punktu widzenia historii kartografii istotne jest potwierdzenie hipotezy, że

* Artykuł powstał w ramach projektu badawczego Narodowego Centrum Nauki Opus (nr 2014/15/B/HS2/01104) pt. Zwiazki literatury polskiej i kartografii w XVI - I poł. XVII w. oraz dzięki wsparciu Fundacji z Brzezia Lanckorońskich (Nr 41-4/17).

${ }^{1}$ Marek Ferenc, Mikołaj Radziwitł „Rudy” (1515-1584), Kraków 2008, s. 574-575; Piotr ŁABĘDŹ, Działalność wojskowa Krzysztofa Radziwiłła „Pioruna” w latach 1572-11579, Zapiski Historyczne (dalej cyt. ZH), t. 76: 2011, z. 1, s. 36-37; Henryk KotARsкI, Wojsko polsko-litewskie podczas wojny inflanckiej 1576-1582. Sprawy organizacyjne. Część II, Studia i Materiały do Historii Wojskowości, t. 17: 1971, cz. 1 (dalej cyt. H. KotARski, Wojsko polsko-litewskie [cz. 2]), s. 74-75; Dariusz KuPIsz, Połock 1579, Warszawa 2003, s. 98-99; Tadeusz Korzon, Dzieje wojen i wojskowości w Polsce, t. 2, Kraków 1912, s. 33; Henryk Lulewicz, Radziwiłt Krzysztof zwany Piorunem, [in:] Polski słownik biograficzny (dalej cyt. PSB), t. 30, Wrocław 1987, s. 264-276; Marek PlewCZyŃski, Wkład Radziwiłłów w rozwój staropolskiej sztuki wojennej XVIw., Miscellanea Historico-Archivistica, t. 7: 1997, s. 33-34.

${ }^{2}$ Российская национальная библиотека, Санкт-Петербург (dalej суt. РНБ), Ф. 971, Авт. 321/1, № 9, k. 8. Do obiegu naukowego informacje o źródle wprowadził Stanisław Alexandrowicz, który ustalił punkt docelowy i zestawił wykaz niektórych miejscowości z wyprawą Krzysztofa Radziwiłła przeprowadzoną na początku 1579 r. Ten wybitny znawca kartografii wojskowej nie pokusił się jednak o analizę źródła w kontekście działań wojennych, zob. Stanisław Alexandrowicz, Rozwój kartografii Wielkiego Księstwa Litewskiego od XV do połowy XVIII wieku, Poznań 1989, s. 193; idem, Kartografia Wielkiego Księstwa Litewskiego od XV do połowy XVIII wieku, Warszawa 2012, s. 170. 
planowanie działań wojennych opierało się na uwzględnieniu map, a szerzej: wiedzy geograficznej.

Kolejnym istotnym źródłem uzupełniającym naszą wiedzę o tej wyprawie jest nabyty przez Muzeum Wojska w Warszawie w 1993 r. rysunek przedstawiający zdobycie zamku Kierepeć (Kirempe, est. Kirumpää, niem. Kirrumpäh) w 1579 r. $^{3}$ Źródło to wykonano w latach 1784-1791, kiedy Stanisław August Poniatowski zamówił rysunki przedstawiające obrazy znajdujące się w zbiorach Radziwiłłowskich ${ }^{4}$. Istotne znaczenie faktograficzne ma również niewykorzystywany dotychczas poemat Andrzeja Rymszy pt. Deketeros akroama, to jest dziesięćroczna powieść wojennych spraw oświeconego książęcia i pana, pana Krzysztofa Radziwiła . Podkreślić należy, że twórca nie tylko był klientem domu Radziwiłłów birżańskich, lecz także żołnierzem uczestniczącym w wyprawach Krzysztofa Radziwiłła „Pioruna” z lat 1579-15816.

Szczególnym przypadkiem sztuki manewrowej, w mojej ocenie przełomowym, była wyprawa zbrojna Krzysztofa Radziwiłła „Pioruna” do Inflant, przeprowadzona zimą 1579 r. Pierwszy plan wyprowadzenia czaty opracował w styczniu 1579 r. Andrzej Sapieha. Zamierzał on dokonać wypadu pod Dorpat $\mathrm{z}$ wojskiem liczącym ok. 1300 koni. Krzysztof Radziwiłł, przejmując dowództwo nad wojskiem "inflanckim”, wstrzymał ten projekt i postanowił przygotować ofensywę zakrojoną na większą skalę. Poinformował kanclerza wielkiego koronnego Jana Zamoyskiego i ojca (Mikołaja Radziwiłła) o zamiarze osobistego przeprowadzenia ataku na Dorpat, gdzie stacjonować miały siły rosyjskie liczące ok. 6000 jazdy i 2000 piechoty. W planach było pokonanie tej armii (w polu) oraz spustoszenie okolicznych ziem. Ostateczna zgoda została podjęta osobiście przez Stefana Batorego, który w ten sposób postanowił skupić uwagę Rosjan na Inflantach wobec planowanego uderzenia na Połock ${ }^{7}$.

O przebiegu samej wyprawy wiemy niewiele. Dosyć zgodnie historycy oceniają siłę pułku na 2250 konnych (2050 husarzy, 150 petyhorców i 50 koza-

${ }^{3}$ Muzeum Wojska Polskiego w Warszawie, nr inw. $16596 \mathrm{~A}^{\star}$; wierszowany opis umieszczony pod rysunkiem został wydany w: Teofil Żebrawski, O pieczęciach dawnej Polski i Litwy, Kraków 1865, s. 53, nr 8 (jest to dodatek do książki o odrębnej numeracji).

${ }^{4}$ Marek A. JANICKI, Obraz Bitwa pod Orsza - geneza, datowanie, wzory graficzne a obraz bitwy „na Kropiwnej” i inne przedstawienia batalistyczne w wileńskim pałacu Radziwiłłów, [in:] Bitwa pod Orsza, red. Mirosław NAGIELski (Biblioteka Epoki Nowożytnej, nr 3), Warszawa 2015, s. $212-217$.

${ }^{5}$ Wojciech Ryszard Rzepka, Alojzy Sajкowski, Andrzeja Rymszy „Dziesięćroczna powieść wojennych spraw..." (1585), [in:] Miscellanea staropolskie, t. 4, Wrocław-Warszawa-Kraków-Gdańsk 1972, s. 121-132. Tekst źródłowy: ibid., s. 133-224.

${ }^{6}$ Henryk Lulewicz, Rymsza Andrzej h. Gozdawa, [in:] PSB, t. 33, Wrocław 1991-1992, s. $532-533$.

${ }^{7}$ M. Ferenc, op.cit., s. 574-575; P. ŁabęDź, op.cit., s. 36-37; M. Plewczyński, op.cit., s. 33-34; H. KotARSKI, Wojsko polsko-litewskie [cz. 2], s. 74-75; D. KupIsz, op.cit., s. 98-99. 
ków), nic jednak nie wspomina się o piechocie i artylerii ${ }^{8}$. Podaje się ponadto, że koncentracja wojsk nastąpiła w bliżej niesprecyzowanej okolicy środkowej Dźwiny (Dariusz Kupisz, Piotr Łabędź), a wyprawa trwała od lutego do połowy marca 1579 r. Skutkiem działań armii Krzysztofa Radziwiłła było dokonanie rozległych spustoszeń okolic Dorpatu oraz zdobycie zamku Kierepeć. Najczęściej wskazuje się, że „Piorun” zdobył fortyfikacje 11 lutego (Henryk Lulewicz, Marek Plewczyński), ewentualnie 2-3 marca (Piotr Łabędź). Nie ma zgodności w kolejności zdarzeń. Dariusz Kupisz wskazuje, że najpierw zdobyto zamek, następnie spustoszono okolice Dorpatu, natomiast Piotr Łabędź i Marek Ferenc uznają odwrotną kolejność. Podsumowując ten rajd, M. Plewczyński stwierdza, że była to pierwsza tego typu wyprawa w karierze Krzysztofa Radziwiłła, od tej pory współcześni uznali go za „czołowego zagończyka”.

Oczywiście brak szczegółowych opracowań wynika z ubogiej bazy źródłowej. Główny kronikarz epoki Reinhold Heidenstein scharakteryzował tę wyprawę właściwie jednym zdaniem: „Napadł on [Krzysztof Radziwiłł - K.Ł.] był na nieprzyjacielską ziemię aż do Dorpatu i szeroko ją spustoszył, a potem za jednym pędem i Kirempesją zabrał i zburzył" ". Równie krótko opisał całą wyprawę Jan Zamoyski w liście do Jerzego Radziwiłła. Kanclerz wielki koronny informował, że Krzysztof Radziwiłł „znaczną przeciw themu nieprzyiaczielowi posługę uczinil: woyowal yego ditiones okolo Derpatu, ucziniwszy wiazdę z ludzmi zolnierskiemy dobrze glęboko; miasto Derpt opalił; zamek Kerepeth wzial y zborzil, na niem ludzi niemalo pobral y dzial kilka, zywnosczy bardzo wiele, którą popalił, korzisczy y plonu wygnaly doszicz, ludzi na kilka tysienczy a bydla kilkanasczie”11. Opis czynów wojennych „Pioruna” zawartych w anonimowym Res Moscoviticae również zawiera ogólne informacje, podając do tego błędną datę wyprawy (1577 r. $)^{12}$. Podobnie ogólną wzmiankę o wyprawie K. Radziwiłła i upadku Kiriempe przedstawia Hieronim Rozdrażewski ${ }^{13}$.

${ }^{8}$ P. ŁABĘDŹ, op.cit., s. 36-37; M. PleWCZyński, op.cit., s. 33-34; H. KotARski, Wojsko polsko-litewskie [cz. 2], s. 74-75; D. KupIsz, op.cit., s. 98-99. Nieco inne liczby podają: H. LulEwICZ, Radziwiłł Krzysztof, s. 264-276 („ponad 2000 koni”); M. FERENC, op.cit., s. 575 (1950 żołnierzy).

${ }^{9}$ M. PlewCZyŃski, op.cit., s. 34.

${ }^{10}$ Reinhold Heidenstein, Dzieje Polski od śmierci Zygmunta Augusta do roku 1594, tłum. Michał Gliszczański, wstęp Włodzimierz Spasowicz, t. 1-2, Petersburg 1857, tu: t. 1, s. 303. Por. Reinold Heidenstein, De Bello Moscovitico Commentariorum, Cracoviae 1584, s. 38.

${ }^{11}$ J. Zamoyski do J. Radziwiłła, Wilno 1 IV 1579 r., [in:] Archiwum Jana Zamoyskiego kanclerza i hetmana wielkiego koronnego, t. 1: 1553-1579, wyd. Wacław SoBIESKI, Warszawa 1904, s. 307 .

${ }^{12}$ Biblioteka Kórnicka, rkps. 1538, k. 1-1v.

${ }^{13}$ H. Rozdrażewski do Hozjusza, Wilno 10 IV 1579 r., [in:] Korespondencja Hieronima Rozrażewskiego, t. 1: 1567 - 2 VII 1582, wyd. Paweł CzAPlewski, Toruń 1937, s. 272. Prawdopodobnie Rozdrażewski opisał dokładniej całą wyprawę, list ten jednak się nie zachował: H. Rozdrażewski do Bogurskiego, Wilno 1 V 1579 r., [in:] ibid., s. 276. 
Już na wstępie warto odnotować, że wyprawę należy przesunąć na drugą połowę lutego, gdyż jeszcze 14 lutego Krzysztof Radziwiłł wysłał z Kiesi (Wenden) list do Stefana Batorego ${ }^{14}$. List ten koreluje z przyjazdem króla do Grodna, gdzie 16-17 lutego odbyła się narada senatorów, na której zgodzono się na plan K. Radziwiłła ${ }^{15}$. To uprawdopodabnia, że koncentracja sił litewskich nie nastąpiła w bliżej nieokreślonym środkowym biegu Dźwiny, tylko zgodnie z pierwotnym planem Andrzeja Sapiehy w Kiesi. Tym samym wątpliwa jest również data zdobycia zamku Kierepeć - 11 lutego.

Moje wyobrażenie o tej czacie całkowicie zburzyło niepozorne źródło niewielka karteczka przechowywana w Autografach Dubrowskiego w Bibliotece Narodowej w Petersburgu z adnotacją archiwalną „circa anno 1579”. W rzeczywistości jest to itinerarium planowanej marszruty wojsk z Kiesi (Wenden) do Dorpatu. Zachowany opis dróg jest cenny z dwóch powodów. Po pierwsze, wskazuje na to, że K. Radziwiłł, planując trasę ataku, przygotował trzy różne trasy. Hipotetycznie itinerarium może stanowić dowód na podzielenie armii na trzy samodzielne pułki (prawy, centralny i lewy). Wszystkie one miały wyruszyć z Kiesi, a punktem docelowym był Dorpat. Po drugie, odnotowano tu dokładnie (w milach) odległości między poszczególnymi miejscowościami, co pozwala na szczegółową analizę zaplanowanych tras i ustalenie precyzji wykonanego itinerarium ${ }^{16}$.

Itinerarium podaje odległości w milach. Ale o jakich jednostkach jest tu mowa? Niewątpliwie współcześni mile traktowali w sposób umowny, użytkowy, jako określoną liczbę kroków, jednak także ona nie była stała i mogła wynieść 4000, 4500 lub 5000 kroków podwójnych (passus), czyli odpowiednio 6277,7062 i $7846 \mathrm{~m}^{17}$. Należy sądzić, że przed epoką dokładnych pomiarów kartograficznych mila stanowiła odległość w znacznej mierze uznaniową, opartą na subiektywnym odczuciu ${ }^{18}$. Mapa Radziwiłłowska Makowskiego

${ }^{14}$ K. Radziwiłł do Stefana Batorego, Wenden 14 II 1579 r., Archiwum Główne Akt Dawnych w Warszawie, Archiwum Zamoyskich, rkps. 3112, s. 8-10. Na źródło to uwagę zwrócił H. Kotarski, zob. idem, Wojsko polsko-litewskie [cz. 2], s. 74, przyp. 103.

${ }^{15}$ P. ŁABĘDŹ, op.cit., s. 37.

${ }^{16}$ РНБ, Ф. 971, Авт. 321/1, № 9, k. 8.

${ }^{17}$ Stanisław Solski, Geometra polski to jest nauka rysowania, podziału, przemieniania y rozmierzania linyi, angułów, figur i brył pełnych, cz. 2, Kraków 1643, s. 145-146. Por. Gregorius Knapiusz, Thesaurus polono-latino-graecus seu promptuarium lingua Latinae et Graece [...], t. 1, Cracoviae 1643, s. 411; Edward Stamm, Staropolskie miary, cz. 1: Miary długości i powierzchni, Warszawa 1938, s. 32; Marek WREDE, Itinerarium króla Stefana Batorego 1576-1586, Warszawa 2010, s. 41-42 (utożsamia milę z 10000 krokami).

${ }^{18}$ Witold Kula, Miary i ludzie, Warszawa 1970, passim (w szczególności s. 11-12, 612-613). Warto zwrócić uwagę, że dopiero w drugiej połowie XVI w. pojawiają się na wyposażeniu inżynierów i kartografów krokomierze, czyli pedometry (Schrittzähler). Zob. Paul PFInZING, Methodvs Geometrica, Nürnberg 1598, k. XLv; Helmut Minow, Historische Vermessungsinstrumente. Ein Verzeichnis der Sammlungen in Europa, Wiesbaden 1990, s. 201-202. 
z 1613 r. podaje różne wartości: milliaria magna liczyła $7370 \mathrm{~m}$, mediocria $6336 \mathrm{~m}$, a communia sive usitata zaledwie $5560 \mathrm{~m}^{19}$, czyli mila odpowiadała 10000, 9000 lub 8000 kroków. Moje obliczenia mili odnotowanej przez Stanisława Pachołowieckiego rysującego w 1579 r. mapę księstwa połockiego wskazują, że wynosiła ona zaledwie $5 \mathrm{~km}$, a zatem była znacznie mniejsza od mili małej $^{20}$. Z kolei Grzegorz Knapski w dziele Thesaurus (po raz pierwszy wydanym w roku 1621) podał definicję mili opartą na łokciach krakowskich. Przy założeniu, że te liczyły 59,5 cm, otrzymujemy długość mili równą 7933,33 m²1, czyli jeszcze większą odległość niż mila wielka.

Itinerarium powinno pozwolić określić, co Krzysztof Radziwiłł „Piorun” rozumiał pod pojęciem mili. Inflanty nie były bowiem terra incognita - to obszar mający (jeszcze) liczne zamki i miasta połączone traktami, między którymi odbywał się ożywiony handel. Dewastująca wyprawa sił moskiewskich z 1577 r. nie mogła jeszcze w stopniu zasadniczym doprowadzić do zarośnięcia traktów.

Poniżej przedstawiam trzy tabele, w których analizuję trasę przemarszu dla pułku lewego, centralnego i prawego. Oprócz nazw miejscowości i odnotowanych w źródle odległości ukazuję również odległość w linii prostej. Ostatnia kolumna prezentuje uśrednioną długość mili odcinku²2.

Tabela 1. Planowana trasa pułku lewego skrzydła

\begin{tabular}{|l|c|c|c|}
\hline \multicolumn{1}{|c|}{ Odcinek trasy pułku skrzydła lewego } & $\begin{array}{c}\text { Odległość } \\
\text { odnotowana }\end{array}$ & $\begin{array}{c}\text { Odległość } \\
\text { w linii prostej }\end{array}$ & $\begin{array}{c}\text { Wartość } \\
1 \mathrm{mili}\end{array}$ \\
\hline Kieś (Wenden) - Trikatski Przewóz (Trikāta) & $6 \mathrm{mil}$ & $44,28 \mathrm{~km}$ & $7,38 \mathrm{~km}$ \\
\hline $\begin{array}{l}\text { Trikatski Przewóz (Trikāta) - Rindoch (Rõn- } \\
\text { gu/Ringen) }\end{array}$ & $6 \mathrm{mil}$ & $70,65 \mathrm{~km}$ & $11,77 \mathrm{~km}$ \\
\hline Rindoch (Rõngu/Ringen) - Dorpat (Tartu) & $6 \mathrm{mil}$ & $38,11 \mathrm{~km}$ & $6,35 \mathrm{~km}$ \\
\hline
\end{tabular}

${ }^{19}$ Stanisław Alexandrowicz, Mapa Wielkiego Księstwa Litewskiego Tomasza Makowskiego z 1613 r. tzw. „radziwiłłowska”, jako źródło do dziejów Litwy i Białorusi, Studia Źródłoznawcze, t. 10: 1965, s. 39; Jarosław Łuczyński, Przestrzeń Wielkiego Księstwa Litewskiego na mapie radziwiłłowskiej Tomasza Makowskiego z 1613 r. w świetle treści kartograficznej i opisowej, $\mathrm{ZH}$, t. 78: 2013, z. 1, s. 76. Por. D. [pseudonim - K.Ł.], Wyjaśnienie: jaka była długość mili słusznej, używanej w r. 1669 w dzisiejszych zachodnich guberniach cesarstwa, Biblioteka Warszawska, t. 2: 1854, s. 582-585; Juliusz KolBerg, Porównanie miar i wag teraźniejszych i dawniejszych w Królestwie Polskiem używanych z zagranicznemi, przerobił i powiększył Wilhelm KolbERG, Warszawa 1838 , s. $16-18$.

${ }^{20}$ Karol Łopatecki, Okoliczności powstania i przydatność wojskowa „Descriptio ducatus Polocensis" Stanisława Pachołowieckiego (1580), Terminus, t. 19: 2017, z. 1, s. 119. Dotychczasowe obliczenia S. Alexandrowicza (idem, Kartografia Wielkiego Księstwa Litewskiego, s. 60-61) wskazywały, że mila liczyła 5,6 km.

${ }^{21}$ Por. E. Stamm, op.cit., s. 33.

${ }^{22}$ Wszystkie tabele wykonuję, bazując na zachowanym itinerarium: РНБ, Ф. 971, Авт. 321/1, № 9, k. 8. 
Pułk lewy miał wyruszyć z Kiesi (Wenden) do Trikatskiego Przewozu. Punkt docelowy należy utożsamić z miejscowością Trikāta (niem. Trikaten, pol. Trykat) ${ }^{23}$. Jest ona położona nad rzeką Abuls (Abulite), która stanowi lewy dopływ rzeki Gauja (określanej w źródłach jako rzeka Aa). Rzeka ta stanowiła jedyną istotną przeszkodę rzeczną podczas tej wyprawy, co związane jest nie tylko z jej szerokością, lecz także z pogłębionym na tym odcinku korytem i wysokimi, skalistymi brzegami ${ }^{24}$. W rzeczywistości więc ten etap podróży nie wiąże się z Trykatem, a podaną odległość powiększam o $7 \mathrm{~km}$ i o tyle samo skracam drugi etap (co odnotowano w tabeli). Następnie oddziały miały się udać do zamku Rindoch (Rõngu/Ringen), a ostatnim etapem podróży był Dorpat (Tartu).

Wyprawa została w założeniu zaplanowana na trzy równe części, liczące po sześć mil. W rzeczywistości błędnie obliczono drugi etap podróży, gdyż był on dłuższy o 59,5\% w stosunku do pierwszego etapu i aż o 85,3\% dłuższy od trzeciego. Być może ta aberracja wynikała z uwzględnienia przeprawy przez rzekę Aa, która to czynność została włączona w ogólne obliczenia.

Jeżeli uśrednimy całą trasę, to na 18 mil przypadało 153,04 km, czyli jedna mila równa się $8,5 \mathrm{~km}$. Warto również uwzględnić to, że dzięki punktom postojowym cała trasa wydłużyła się zaledwie o 4\%, gdyż z Kiesi do Dorpatu w linii prostej jest $147,19 \mathrm{~km}$.

Tabela 2. Planowana trasa pułku głównego

\begin{tabular}{|l|c|c|c|}
\hline \multicolumn{1}{|c|}{ Odcinek trasy pułku centralnego } & $\begin{array}{c}\text { Odległość } \\
\text { odnotowana }\end{array}$ & $\begin{array}{c}\text { Odległość } \\
\text { w linii prostej }\end{array}$ & $\begin{array}{c}\text { Wartość } \\
1 \mathrm{mili}\end{array}$ \\
\hline Kieś (Wenden) - Trikatski Przewóz (Trikāta) & $5 \mathrm{mil}$ & $37,28 \mathrm{~km}$ & $7,45 \mathrm{~km}$ \\
\hline $\begin{array}{l}\text { Trikatski Przewóz (Trikāta) - Walek (Walk/ } \\
\text { Valga) }\end{array}$ & 3 mile & $32,26 \mathrm{~km}$ & $10,75 \mathrm{~km}$ \\
\hline Walek (Walk/Valga) - Sangnitz (Sangaste) & 2 mile & $24,23 \mathrm{~km}$ & $12,11 \mathrm{~km}$ \\
\hline $\begin{array}{l}\text { Sangnitz (Sangaste) - Odtepla (Odenpa/Ote- } \\
\text { pää) }\end{array}$ & $3 \mathrm{mile}$ & $17,64 \mathrm{~km}$ & $5,88 \mathrm{~km}$ \\
\hline Odtepla (Odenpa/Otepää) - Dorpat (Tartu) & $6 \mathrm{mil}=48 \mathrm{~km}$ & $38,14 \mathrm{~km}$ & $6,35 \mathrm{~km}$ \\
\hline
\end{tabular}

Pułk główny (centralny) miał przebyć w założeniu trasę dłuższą o jedną milę (19 mil) niż pułk lewy. Rzuca się w oczy, że przygotowano go bardziej pieczołowicie niż plan ciągnienia lewego pułku. Pierwsza część podróży po-

${ }^{23}$ Stownik geograficzny Królestwa Polskiego i innych krajów słowiańskich, t. 12, red. Bronisław Chlebowski, Warszawa 1892, s. 476.

${ }^{24}$ W. K. [Walery Kopernicki], Rzeki i jeziora. Tekst objaśniajacy do mapy hydrograficznej dawnej Słowiańszczyzny części pótnocno-zachodniej, Warszawa 1883, s. 47; Słownik geograficzny Królestwa Polskiego i innych krajów słowiańskich, t. 2, red. Filip Sulimierski, Bronisław ChleBOWSKI, Władysław WALEWSKI, Warszawa 1881, s. 500. 
winna dotrzeć do Trykackiego Przewozu podobnie jak pułk lewy. Podano jednak inne odległości (5 i 6 mil), co oznacza, że od początku oba pułki podróżować powinny oddzielnie, innymi drogami, być może również przeprawa przez Gauję była w różnych miejscach. Następnie pułk główny kierować się powinien do miasta Walga (Walk/Valga) ${ }^{25}$. Kolejnym jego przystankiem miał być zamek Sangnitz (Sangaste, Schloss Sagnitz). W sumie ta połowa trasy była znacznie niedoszacowana, w szczególności mila na drugim i trzecim odcinku wynosiła odpowiednio 10,75 i 12,11 km, wobec 5,88 km w czwartym etapie. Na szczęście pozostałe odcinki, czyli do Odtepli (Odenpa, Otepää) ${ }^{26}$ i Dorpatu (Tartu) były relatywnie krótsze. Skoro cała trasa liczyła 149,55 km, to jedna mila wynosiła 7,87 km. Należy podkreślić, że uwzględnienie pięciu punktów przystankowych niemal nie wydłużyło całej trasy, która stała się dłuższa zaledwie o $2,38 \mathrm{~km}(1,6 \%)$.

Tabela 3. Planowana trasa pułku skrzydła prawego

\begin{tabular}{|l|r|c|c|}
\hline \multicolumn{1}{|c|}{ Odcinek trasy pułku skrzydła prawego } & $\begin{array}{r}\text { Odległość } \\
\text { odnotowana }\end{array}$ & $\begin{array}{c}\text { Odległość } \\
\text { w linii prostej }\end{array}$ & $\begin{array}{c}\text { Wartość } \\
1 \text { mili }\end{array}$ \\
\hline $\begin{array}{l}\text { Kieś (Wenden) - Bebel (zamek: Piebalgas pils, } \\
\text { Pebalg; wieś: Vecpiebalga) }\end{array}$ & $\begin{array}{r}43,13 \mathrm{~km} \\
\text { brak danch } \\
{[6 \text { mil] }}\end{array}$ & $\begin{array}{c}- \\
{[7,18 \mathrm{~km}]}\end{array}$ \\
\hline $\begin{array}{l}\text { Bebel (Piebalgas pils, Pebalg) - Birżmujza } \\
\text { (Birże Inflanckie, Bērzpils pagasts) }\end{array}$ & $\begin{array}{r}\text { brak danych } \\
{[6 \mathrm{mil}]}\end{array}$ & $80,86 \mathrm{~km}$ & $\begin{array}{r}- \\
{[13,47 \mathrm{~km}]}\end{array}$ \\
\hline $\begin{array}{l}\text { Birżmujza (Birże Inflanckie, Bērzpils pagasts) } \\
- \text { Szwanbork (Gulbene, Schwanenburg) }\end{array}$ & $\begin{array}{r}\text { brak danych } \\
{[6 \mathrm{mil}]}\end{array}$ & $42,55 \mathrm{~km}$ & $\begin{array}{r}- \\
{[7,09 \mathrm{~km}]}\end{array}$ \\
\hline $\begin{array}{l}\text { Szwanbork (Gulbene, Schwanenburg) - Ma- } \\
\text { rienburg (Alūksne) }\end{array}$ & $6 \mathrm{mil}$ & $33,05 \mathrm{~km}$ & $5,05 \mathrm{~km}$ \\
\hline $\begin{array}{l}\text { Marienburg (Alūksne) - Kierepeć (Kirempe, } \\
\text { Kirumpää) }\end{array}$ & $6 \mathrm{mil}$ & $49,3 \mathrm{~km}$ & $8,21 \mathrm{~km}$ \\
\hline $\begin{array}{l}\text { Kierepeć (Kirempe, Kirumpää) - Dorpat (Tar- } \\
\text { tu) }\end{array}$ & $6 \mathrm{mil}$ & $59,41 \mathrm{~km}$ & $9,9 \mathrm{~km}$ \\
\hline
\end{tabular}

Pułk skrzydła prawego ma trasę zupełnie odmienną od dwóch opisanych szlaków. Pierwsza część drogi skierowana była w kierunku południowo-wschodnim, która zupełnie nie była kompatybilna $\mathrm{z}$ kierunkiem na zamek i miasto Dorpat (zob. il. 1). Oddziały miały najpierw skierować się na zamek Bebel (Piebalgas pils, Pebalg) ${ }^{27}$, a następnie na Birżmujzę (Birże Inflanckie,

${ }^{25}$ Osada ta prawa miejskie uzyskała od Stefana Batorego pięć lat później - w 1584 r., zob. Roman Czaja, Miasta inflanckie i estońskie w XIII-XVI wieku, [in:] Inflanty w średniowieczu: władztwa zakonu krzyżackiego i biskupów, red. Marian Biskup, Toruń 2002, s. 58.

${ }^{26}$ Armin Tuulse, Die Burgen in Estland und Lettland, Dorpat 1942, s. 51-52.

${ }^{27}$ Andrzej Rachuba, Obraz działalności publicznej nielubianego bohatera. Uwagi w związku z praca Arkadiusza Czwołka o Lwie Sapieże, Kwartalnik Historyczny, R. 122: 2015, nr 2, s. 341. Być może z zamku tego zabrać miano załogę. W spisanym na potrzeby Mikołaja i Krzysz- 
Bērzpils pagasts) ${ }^{28}$. Wytłumaczeniem wyboru tej trasy może być chęć połączenia się z wojskami księstwa Kurlandii i Semigalii. Dalszy szlak prowadził południowo-wschodnimi rubieżami Inflant przez zniszczony w 1577 r. przez Rosjan Szwanbork (Gulbene, Schwanenburg) ${ }^{29}$ i Marienburg (Alūksne) ${ }^{30}$. Trasa wchodziła głęboko w ziemie zajęte w 1577 r. przez wojska Iwana Groźnego $^{31}$. W trasie przemarszu zwraca uwagę uwzględnienie znajdującego się w rękach wroga zamku Kirempe (Kierepeć). Tym samym itinerarium stanowi uzewnętrznienie planu zdobycia zamku w momencie, kiedy dwa pozostałe pułki będą już znajdować się w okolicach Tartu (Dorpatu). Działanie takie uniemożliwiałoby stronie rosyjskiej wysłanie posiłków do atakowanego zamku. Odmienna trasa pozwalała również na dokonanie znacznie szerszej strefy zniszczeń i grabieży pogranicza rosyjskiego. Warto podkreślić, że w świetle Wiadomości kędy w ziemię nieprzyjacielska iśćc $c^{32}$ z 1570 r. między Marienburgiem a Kierepecią istniała trasa zwana „gościńcem wielkim”.

Niestety na kartce nie zachowały się odległości pierwszych etapów podróży. Również na tej trasie różnice w długości mili są olbrzymie i wahają się od 5,05 km do 9,9 km. Trzy ostatnie etapy liczą 141,78 km i uśredniając tę trasę, mila wynosi 7,87 km. Gdy przyjmiemy założenie, że wszystkie sześć etapów uznano za równe i każdy był oceniony na 6 mil, to wówczas w linii prostej trasa wynosiła $308,3 \mathrm{~km}$, a przeciętna mila $8,56 \mathrm{~km}$.

Podsumowując, przeciętna odległość mil na wszystkich trasach jest do siebie bardzo zbliżona i wynosi odpowiednio $8,5 \mathrm{~km}-7,87 \mathrm{~km}-7,87$ [lub $8,56] \mathrm{km}$. Uśredniając, możemy założyć, że mila używana przez Krzysztofa Radziwiłła „Pioruna” liczyła aż 8,07 km. Jest to zatem nieco większa odległość, niż przewidywała mila wielka. Niepokoi jednak inne zjawisko. Są to bardzo duże różnice mil na poszczególnych odcinkach od 5,05 km do 12,11 km. Druga kwestia to ogromna różnica wobec wykonanej w tym samym roku mapy Stanisława Pachołowieckiego, gdzie mila wynosi $5 \mathrm{~km}$.

tofa Radziwiłłów zestawieniu wojsk inflanckich z 1579 r. odnotowano zamek „Bebel”, nie wymieniono jednak liczebności stacjonującego tam oddziału, zob. РНБ, Ф. 971, Авт. 321/1, № 10, k. 17. Jest to znacznie dokładniejszy spis niż wymieniony w pracy: H. KotarsKi, Wojsko polsko-litewskie [cz. 2], s. 118. Zob. Kasper Niesiecki, Herbarz Polski, t. 3, wyd. Jan N. Bobrowicz, Lipsk 1839, s. 323.

${ }^{28}$ Stownik geograficzny Królestwa Polskiego i innych krajów słowiańskich, t. 1, red. Filip SuliMIERski, Bronisław Chlebowski, Władysław WALEwski, Warszawa 1880, s. 232-233.

${ }^{29}$ Baltisches historisches Ortslexikon, hrsg. v. Hans Feldmann, Heinz von zur MüHLen, Teil 2: Lettland (Südlivland und Kurland), bearb. v. Hans Feldmann, Richard von Kymmel, Dagmar Lydike $(\dagger)$, Heinz von zur Mühlen, Clara Redlich, Sigrid Weikert-GirgenSoHN (†), Köln-Wien 1990, s. 566-567.

${ }^{30}$ A. Tuulse, op.cit., s. $146-148$.

${ }^{31}$ P. ŁABĘDŹ, op.cit., s. 29-36.

${ }^{32}$ РНБ, Ф. 971, Авт. 321/1, № 2, k. 5-5v. 
Czy źródła wykonane na potrzeby wojskowe w jednym roku (1579) mogły tak znacząco się różnić? Oczywiście można przyjąć założenie, że Krzysztof Radziwiłł podawał odległości w milach litewskich, które były znacznie większe i w XVII w. liczyły około $8910 \mathrm{~m}^{33}$, Pachołowiecki zaś używał krótkich mil koronnych $^{34}$. Sądzę jednak, że powyższe obliczenia potwierdzają ogólne spostrzeżenie, że mila stanowiła odległość w znacznej mierze uznaniową, opartą na subiektywnym odczuciu. Różnica w odległościach mili na mapach i itinerariach mogła oznaczać łatwiejszy lub trudniejszy teren do przebycia. W ocenie współczesnych mila pozostawała ta sama (przebyta droga w identycznym czasie), ale obiektywnie przebyta odległość była krótsza lub dłuższa. Przyjęcie tego założenia oznacza, że poruszanie się na terenie Połocczyzny i Witebszczyzny było bardzo trudne, co zresztą potwierdzają źródła. Daniel Herman opisuje Połocczyznę słowami: „tam prowadzi okropna droga, gorszej na całym świecie być niemoże. Zdaje mi się, że najgłówniejszą przyczyną tego jest, iż, odkąd Moskwicin zebrał Połock t.j. r. 1563, ten tractus został całkiem zamknięty, wszystkie comeatus odcięta, a Moskwicin na 20 mil wszerz i wdłuż, z tej strony Dźwiny, kraj zamienił w pustynię”. W dalszej części relacji podkreśla: „Jasno też widać, jak Węgrzyni i inni żołnierze, którzy szli przodkiem, musieli szukać nowych dróg i w lasach robić przesieki, aby mogli działa przeprawić”35. Identycznie sytuację opisują Reinhold Heidenstein oraz Joachim Bielski ${ }^{36}$. Tymczasem stan traktów między miastami i zamkami inflanckimi był (jeszcze) bardzo dobry, pozwalający stosunkowo szybko się przemieszczać37. Ogólnie charakterystyka terenu opracowana przez Stanisława Herbsta wskazuje na znaczne zróżnicowanie - obok dobrze utrzymanych dróg i traktów występują tereny podmokłe, puszcze, trudne do przebycia rzeki ${ }^{38}$. Być może więc znacznie zróżnicowany teren wpływał na ogromne wahania odległości mili wyliczone w tabelach $1-3$.

${ }^{33}$ E. STAmm, op.cit., s. 37.

${ }^{34}$ Teza ta jest mało prawdopodobna. Pachołowiecki wykonał swoją mapę bez własnych pomiarów, jeszcze przed wyprawą na Połock. Korzystał z istniejących itinerariów, opisów i map, oczywiście o proweniencji litewskiej, zob. K. ŁopATECKI, Okoliczności powstania, s. 116-117, 119.

${ }^{35}$ Relacja Daniela Hermana miasta Gdańska rajcy i stugi, Wilno 9 X 1579 r., [in:] Wiadomości do dziejów Polskich z Archiwum Prowincyi Szląskiej, wyd. August Mosbach, Wrocław 1860, s. 161.

${ }^{36}$ Reinhold Heidenstein, Dzieje Polski, t. 1, s. 310; t. 2, s. 12, 15; idem, Pamiętniki wojny moskiewskiej w 6 księgach, wyd. i tłum. Jan CzuBeK, Lwów 1894, s. 62; Marcin Bielski, Kronika polska, wyd. Joachim Bielski, Kraków 1597, s. 760.

${ }^{37}$ Por. Tomas ČElKIs, Stan dróg lądowych i struktura systemu połączeń $w$ Wielkim Księstwie Litewskim w końcu XV-XVII wieku, ZH, t. 79: 2014, z. 3, s. 39-60; Bożena Wyrozumska, Drogi w ziemi krakowskiej do końca XVI wieku, Wrocław 1970.

${ }^{38}$ Szczegółowa charakterystyka: Stanisław Herbst, Wojna inflancka: 1600-1602, Warszawa 1938 , s. $11-15$. 


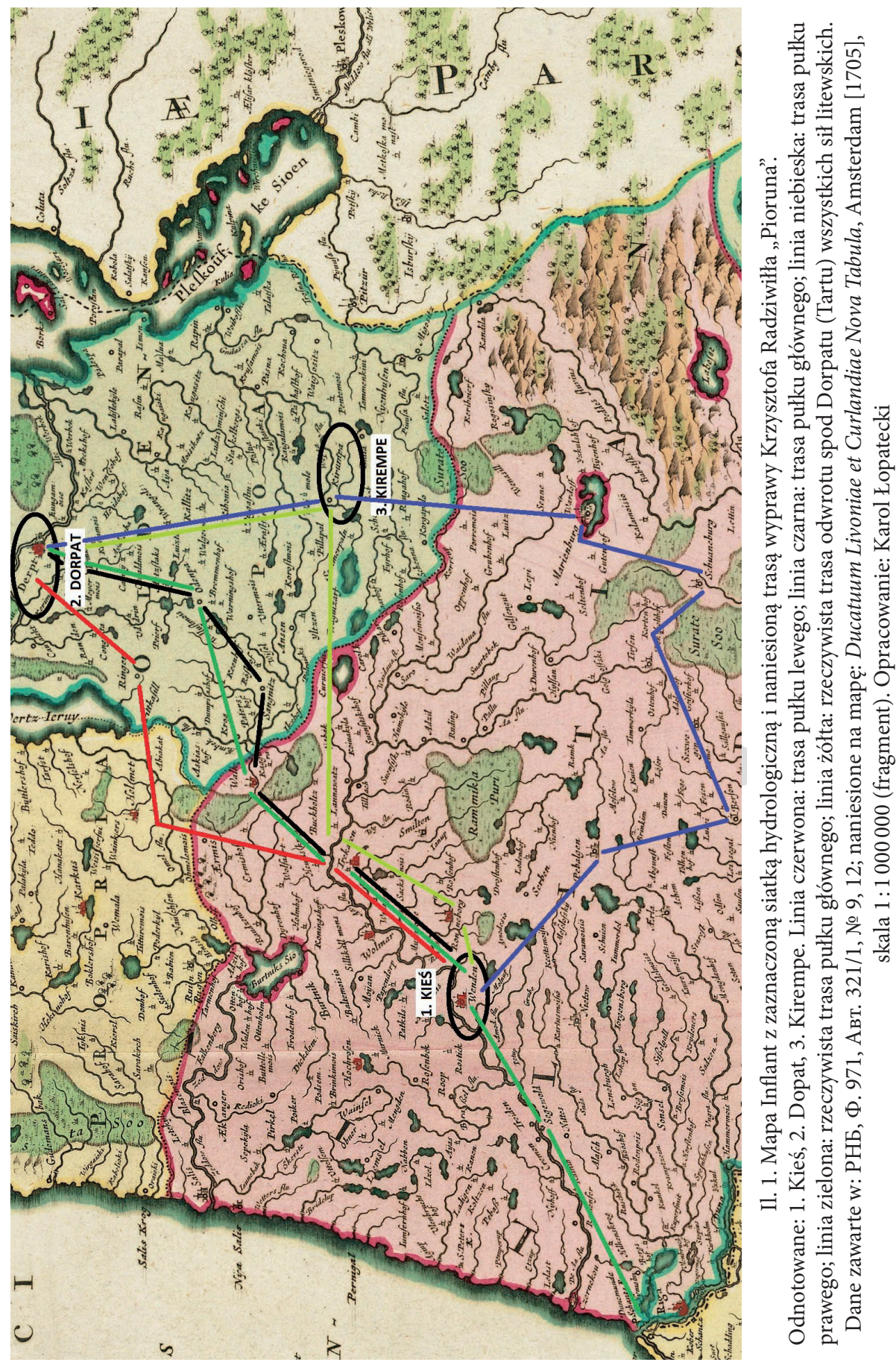


Oceniając itinerarium, stwierdzam, że plany tras wykonano stosunkowo starannie. Można wyraźnie dostrzec, że szlaki lewy i środkowy były w zasadzie do siebie równoległe (zob. il. 1). Zapewniało to możliwość dokonania większych zniszczeń, z pozostawaniem całkowitej koordynacji działań. Zbieżność tych dwóch tras ukazuje tabela 4. Oba pułki powinny pod Dorpat dotrzeć tego samego dnia. Natomiast szlak prawy już podczas prac koncepcyjnych miał znacznie dłużą, samodzielną trasę. Jedynie zachowane trzy ostatnie odcinki równały się całej trasie pułku lewego. Sądzę, że w planach droga ta powinna wynosić co najmniej 36 mil. Trudno uwierzyć, aby czata ta miała podjąć wspólne działania z pozostałymi wojskami, natomiast z pewnością uniemożliwiała koordynację działań wojsk rosyjskich. Głęboka rejza w terytorium moskiewskie od południa mogła przynieść i przyniosła oczekiwane rezultaty. Tym samym wyodrębnienie trzech pułków miało podłoże strategiczne i operacyjne. Możliwe jest, że pułk ciągnący trasą prawą mógł wyruszyć wcześniej niż pozostałe dwa zgrupowania.

Tabela 4. Zestawienie trzech tras przemarszu Kieś-Dorpat

\begin{tabular}{|l|c|c|c|}
\hline- & Droga lewa & Droga środkowa & Droga prawa \\
\hline Planowana trasa & $18 \mathrm{mil}$ & $19 \mathrm{mil}$ & $36(?) \mathrm{mil}$ \\
\hline $\begin{array}{l}\text { Odległość w linii pro- } \\
\text { stej }\end{array}$ & $153,04 \mathrm{~km}$ & $149,55 \mathrm{~km}$ & $308,3 \mathrm{~km}$ \\
\hline
\end{tabular}

Czy możliwe było wykorzystanie mapy podczas planowania trzech tras na Dorpat (Tartu)? Już w początkowym okresie batoriańskim istniały mapy Inflant - zarówno drukowane, jak i przechowywane w rękopisie ${ }^{39}$. Warto odnotować list Piotra Edlinga do Abrahama Orteliusa wysłany z Kołobrzegu 15 VIII 1580 r. Edling zwracał w nim uwage na króla polskiego Stefana Batorego, który posiadał atlas Orteliusa pt. Theatrum Orbis Terrarum i z niego korzystał $^{40}$. Znajdowała się w nim m.in. udana mapa Joanne Portantio pt. Livoniae nova descriptio. Również podczas rozmów pokojowych polsko-moskiewskich była wykorzystywana mapa Inflant. W trakcie negocjacji pisano: „ale iuz s tej strony od Nowogródka, Kierepeczia, Maryenburku y tych zamków, które [...] poszli, Lucen y Rezyca iako sie z malowania zamków malowanych ifflanskih od WM [tj. Jana Zamoyskiego - K.Ł.], danych panu Hara-

${ }^{39}$ Przykładowo: Tõnu RAID, Raffaello Barberini teedekaart aastast 1564, TUNA, vol. 11: 2008, issue 2, s. 7-13, 17-20.

${ }^{40}$ Ecclesiae Londino-Batavae Archivvm, t. 1: Abrahami Ortelii [...] epistvlae, ed. Jan Hendrik Hessels, Cambridge 1887, s. 233: „Sicut regem Poloniae Stephanum intelligo nostro tempore plerumque Theatrum ante oculos habere"; S. Alexandrowicz, Kartografia Wielkiego Księstwa Litewskiego, s. 59. 
burdzie sprawuiemy, iuz rzeczy mamy namówione. Przyczym y zamku Białego Kamienia na stron Kr. JM. ustępuią"41. Oczywiście nie chodzi tu o plany zamków, które nie wnosiłyby niczego w trakcie rozmów międzynarodowych, ale o położenie zamków na terytorium Inflant. Przerysowana kopia tej mapa zachowała się w Archiwum Watykańskim, a szczegółowością znacznie przewyższa powyżej omawianą mapę drukowaną (zob. il. 2a i 2b) ${ }^{42}$. Karol Buczek uważa, że ta rękopiśmienna mapa została stworzona po zajęciu Inflant przez Moskwę i prawdopodobnie była już znana w $1577 \mathrm{r}^{43}$

Jeżeli zestawimy itinerarium $\mathrm{z}$ mapą odnotowaną w atlasie Orteliusa, okaże się, że pułk skrzydła lewego i centralnego zmienia swoje pozycje (pułk środkowy staje się na mapie pułkiem lewym). Ponadto miejscowości odnotowane na trasie przemarszu pułku głównego nie przystają do treści na mapie. Jeżeli jednak dokonamy analogicznych czynności na zachowanej rękopiśmiennej mapie Inflant, otrzymamy bardzo czytelną treść. Oczywiście nie jest to niepodważalny dowód wskazujący na to, że dowódcy polscy i litewscy posiadali rękopiśmienne mapy Inflant, które wykorzystano podczas tworzenia itinerarium z 1579 r. Niewątpliwie jednak hipoteza ta wydaje się prawdopodobna.

Szczęśliwie posiadamy nie tylko źródło wymieniające trzy szlaki planowanej ofensywy, lecz także samą Drogę ciągnienia Je[g]o M[iło]ści do Inflant, tak$\dot{z}$ e miejscia $w$ ziemie nieprzyjacielskiej za granice ifliantska i plądrowania ${ }^{44}$. Już na wstępie podkreślę, że trasa w $90 \%$ pokrywała się z planowanym przemarszem dla pułku centralnego (zob. linię czarną i zieloną na il. 1). Zawarte są tam informacje dużo bardziej szczegółowe. Dowiadujemy się, że „Piorun” 2 lutego był w Semigalii - w mieście Bowsk (Bauska) ${ }^{45}$. Następnie udał się do najważniejszej inflanckiej twierdzy Dynemont (Dźwinoujście, Daugavgrīvas), do której przybył 6 lutego ${ }^{46}$. Kolejnym etapem podróży był zamek Siguld (niem. Segewold, pol. Zygwold). Dotarł do niego 12 lutego i przebywał w nim przez trzy dni. Następnym miejscem postoju była Kieś, gdzie wojsko stacjonowało 15 i 16 lutego. Wybór trasy poprzedzającej samą wyprawę nie był przypadkowy, związany był z działaniami przygotowawczymi. Historycy zgodnie przyjmują, że w skład formowanej armii weszły wszystkie oddziały jazdy będące w Inflantach. Było ich prawdopodobnie mniej niż dotychczas zakładano, gdyż

${ }^{41}$ Posłowie polscy do J. Zamoyskiego, Jam Zapolski 1 I 1582 r., [in:] Archiwum Jana Zamoyskiego kanclerza i hetmana wielkiego koronnego, t. 2: 1580-1582, wyd. Józef Siemieński, Warszawa 1909, s. 215.

${ }^{42}$ Archivio Segreto Vaticano, Segreteria di Stato, Germania, sygn. 93, k. 327.

${ }^{43}$ Karol Buczek, Dorobek kartograficzny wojen Stefana Batorego, Wiadomości Służby Geograficznej, R. 8: 1934, z. 3, s. 9-11.

${ }^{44}$ РНБ, Ф. 971, Авт. 321/1, № 12, k. 21-21v.

${ }^{45}$ Mariusz BalcereK, Księstwo Kurlandii i Semigalii w wojnie Rzeczypospolitej ze Szwecja w latach 1600-1629, Poznań 2012, s. 45-48.

${ }^{46}$ Ibid., s. 50, 52-53. 

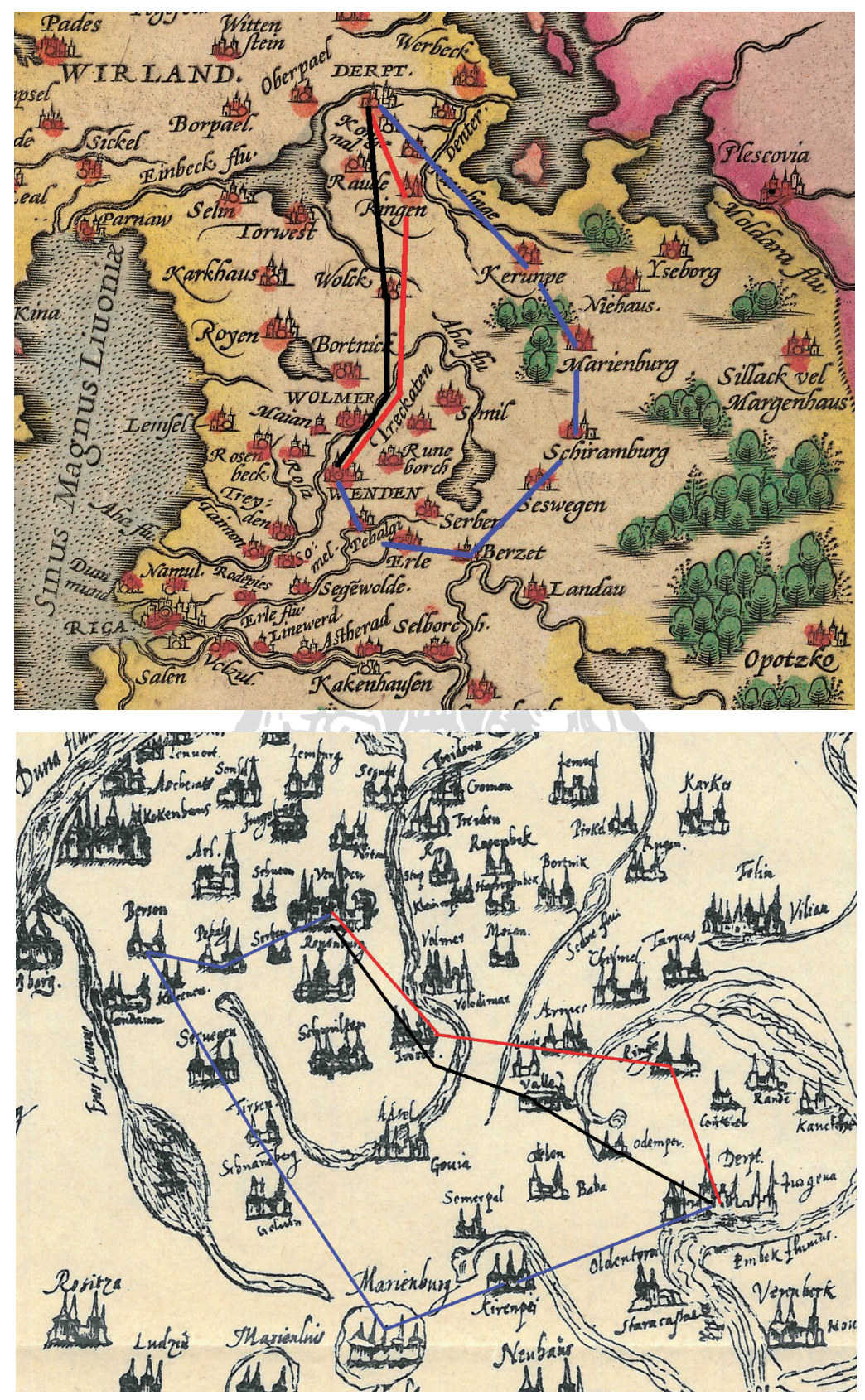

Il. 2. Plan wyprawy pułku lewego (kolor czerwony), centralnego (kolor czarny) i prawego (kolor niebieski) naniesiony na mapę Johannesa Portantiusa (atlas Abrahama Orteliusa) oraz jej rękopiśmienną wersję z przełomu 1581 i 1582 r. Zob. http://www.digar.ee/arhiiv/nlib -digar:977 (dostęp z 12 VII 2017 r.); Karol BuczeK, Dorobek kartograficzny wojen Stefana Batorego, Wiadomości Służby Geograficznej, R. 8: 1934, z. 3, tab. III 
dokładny spis wojsk wykonany w tym czasie wskazuje, że Krzysztof Radziwiłł miał do dyspozycji 1812 konnych, co mógł powiększyć o 140 jazdy będącej na stanie rotmistrzów pieszych. Natomiast pobyt w twierdzy Dźwinoujście, zamku Zygwold i w Kiesi wiązał się z uzupełnieniem sił o oddziały piechoty. W tych trzech punktach przebywało aż 1030 drabów ${ }^{47}$. Uważam, że naczelny wódz mógł zaryzykować zabranie ze sobą przynajmniej 1/3 załogi, co wynosiłoby ok. 340 żołnierzy pieszych. Radziwiłł uzyskał również posiłki od księcia Gottharda Kettlera ${ }^{48}$. Jaki mógł być to rząd wielkości? Jesienią 1579 r. Stefan Batory zażądał wysłania na przyszłą wojnę 300 żołnierzy. W tym celu zebrał się landtag w Doben (7 X 1579 r.), który ustalił, że książę wystawi 100 żołnierzy, a szlachta opodatkuje się w celu zaciągnięcia kolejnych 200. Służba ziemska miała pozostać na terenie księstwa ${ }^{49}$. Jeżeli takie siły miały zostać wysłane po uprzedniej decyzji landtagu, nie wydaje się możliwie, aby K. Radziwiłł mógł pozyskać więcej niż 150-200 żołnierzy, być może dodatkowo kilkudziesięciu ochotników. Ewentualnie do wyprawy mogła przyłączyć się szlachta inflancka, ale z uwagi na szybkość działań nie mogła być to liczba znacząca, co najwyżej kilkudziesięcioosobowa. W wyprawie brali udział również Tatarzy litewscy. Prawdopodobnie było ich ponad 150, wykorzystywano ich do pustoszenia dóbr i łapania jeńcó $w^{50}$.

Jedynym autorem, który dokładnie podaje rząd wielkości pułku „Pioruna", jest uczestnik wyprawy Andrzej Rymsza, który w poemacie Dziesięcioroczna powieść odnotowuje:

$$
\begin{gathered}
\text { "Acz [Krzysztof Radziwiłł - K.Ł.] } \\
\text { nie miał jedno ośm set bojnych ludzi w kupie } \\
\text { A ku temu lancknechtow było z nim sto pieszych, } \\
\text { Falkonetow trzy było z trzemi działek mniejszych" }
\end{gathered}
$$

Dane te, bardzo niskie, wydawały się mało wiarygodne. Jeżeli jednak uwzględnimy itinerarium, które przewiduje utworzenie trzech pułków, okazuje się, że może mamy do czynienia z zadziwiająco spójnymi danymi ukazującymi siłę głównego (centralnego) pułku Radziwiłła. Również na rysunku prezentującym zdobycie Kierepeci (zob. il. 3) oprócz jazdy wyeksponowana

${ }^{47}$ РНБ, Ф. 971, Авт. 321/1, № 10, k. 16-17v.

${ }^{48} \mathrm{Karl}$ H. von Busse, Herzog Magnus, König von Livland: ein fürstliches Lebensbild aus dem 16 Jahrhundert, Leipzig 1871, s. 136; August Seraphim, Die Geschichte Des Herzogtums Kurland (1561-1795), Reval 1904, s. 30-31.

${ }^{49}$ Archiv für die Geschichte Liv-, Est- und Curlands, Bd. 2, Dorpat 1843, s. 226-230.

${ }^{50}$ РНБ, Ф. 971, Авт. 321/1, № 21, k. 57-58v; por. Henryk WiSner, Rzeczypospolita Wazów, t. 2: Wojsko Wielkiego Księstwa Litewskiego, dyplomacja, varia, Warszawa 2004, s. 173

${ }^{51}$ Andrzej Rymsza, Deketeros akroama to jest dziesięćroczna powieść wojennych spraw [...] Krzysztofa Radziwiłła, [in:] W. R. RzePKa, A. SAJKowski, op.cit., s. 151. 
została piechota (trzy roty) - zarówno formacja narodowa, jak i landsknechci oraz dwa działa oblężnicze, co potwierdza relację Rymszy ${ }^{52}$. Sądzę, że łączne siły Krzysztofa Radziwiłła wynosiły ok. 2200 jazdy, ok. 400 żołnierzy pieszych, a także kilka sztuk artylerii. Biorąc pod uwagę, że była to wyprawa łupieżcza ${ }^{53}$, niewątpliwie z wojskiem ciągnęło kilkadziesiąt wozów. Nie była więc to wyprawa komunikiem, co potwierdza tempo marszruty (o czym w dalszej części artykułu).

Droga przebiegała z Kiesi (16 lutego) do Burhartowej Mojzy (18 lutego), Trikatskiego Przewózu (19 lutego), Wałk (20 lutego), trzy mile od Odtepli (21 lutego), następnie półtorej mili za Odteplą (23 lutego), a obóz został założony w siole Karuga, oddalonym 2 mile od Dorpatu (24 lutego). Rajd wojskowy trwał osiem dni, w czasie którego według planu przebyto 16 mil, a w rzeczywistości ok. $172 \mathrm{~km}$. Daje to średnią przemarszu równą 21,5 km dziennie, czyli trasę 2,7 mili. Należy zwrócić uwagę na bardzo ścisłe trzymanie się planu marszruty. Krzysztof Radziwiłł ze swoim pułkiem wyruszył środkową trasą - punktem odniesienia były Burhartowa Mojza, Trikatski Przewóz, Wałk. W drugiej części ciągnienia dostrzec można większą swobodę decyzyjną. Nadal ważnym miejscem była Odtepla, ale już nie odnotowano zamku Sangnitz, zdecydowano się również założyć obóz nie pod murami Dorpatu, ale w siole Karuga oddalonym od miasta o ok. 16 km. Od 24 do 27 lutego nocowano w tym miejscu, zakładając obóz i w tym czasie prowadząc grabież okolicznych terenów ${ }^{54}$. Drogę powrotną spod Kierepeci do Dorpatu pokonano w siedem dni, co daje średnie dzienne tempo rzędu $21,6 \mathrm{~km}$, a zatem w zasadzie identyczne tempo, jak w drodze pod Dorpat ${ }^{55}$. Obciążenie łupami nie spowolniło szybkości przemieszczania się, która w obie strony była równa i wynosiła 2,7 mili dziennie. Warto zestawić te dane z obliczeniami Marka Wredy dotyczącymi przemieszczania się dworu Stefana Batorego. Według tego badacza król, podróżując jedynie z dworem, przemieszczał się stosunkowo szybko, z prędkością 30-35 km. Jednakże przemarsze wojska były dużo wolniejsze i liczyły ok. 2 mil (autor milę utożsamia z $7 \mathrm{~km}$ ), czyli $14 \mathrm{~km}^{56}$. Można więc tem-

${ }^{52}$ Muzeum Wojska Polskiego w Warszawie, nr inw. 16596 A*.

${ }^{53}$ J. Zamoyski do J. Radziwiłła, Wilno 1 IV 1579 r., [in:] Archiwum Jana Zamoyskiego, t. 1, s. 307.

${ }^{54}$ Postępki sławy wiecznej godne wojenne [...] Krzysztopha Radziwiłła, РНБ, Ф. 971, Авт. 321/1, № 143, k. 48: „z kilkiem tysięcy ludzi wielką część ziemie Inflantskiej, która była w possesji kniazia Wielkiego Moskiewskiego splundrował”. Autor odnotowuje również niepotwierdzoną informację: „Derpt miasto spalił”. Zob. Spisanie niektórej części pomiesciej bojarskich okolic Derptu popalionych po 29 in Februario et Marcio, РНБ, Ф. 971, Авт. 152, № 6, k. 17-17v.

${ }^{55}$ Długość trasy obliczono według przyjętej w artykule metodologii. Średnia wyliczona długość trasy samochodowej wynosi 159,6 km, a pieszej 143,6 km. Wartość uśredniona wynosi $151,6 \mathrm{~km}$.

${ }^{56}$ M. WREDE, op.cit., s. 42. 
po marszruty Krzysztofa Radziwiłła uznać jako stosunkowo szybkie, ale chyba nie forsowne.

Pojawia się jeszcze jedno istotne pytanie. Jak na szybkość marszruty i skuteczność wyprawy wpłynęły warunki pogodowe (sezonowe)? Obecnie istniejące badania wskazują, że w czasie wyprawy K. Radziwiłł porą zimową (grudzień-luty) średnia temperatura była niższa aż o $2^{\circ} \mathrm{C}$, lata zaś były nieznacznie cieplejsze niż obecnie ${ }^{57}$. Warto dodać, że w XXI w. średnia temperatura w Dorpacie w lutym wynosi $-7,1^{\circ} \mathrm{C}$, a w marcu $-2,6^{\circ} \mathrm{C}^{58}$. Svetlana Jevrejeva przeanalizowała zamarzanie i rozmarzanie portu w Rydze w latach 1529-1990. Według jej oceny zima 1578/1579 była przeciętna, a takie zimy oznaczały z reguły zniknięcie pokrywy lodowej w porcie ryskim 6 kwietnia (dane z XVIII-XX stulecia $)^{59}$. W mojej ocenie to nie niskie temperatury były przeszkodą, ale warunki hydrologiczne. Niewątpliwie poruszanie się po Inflantach było skrajnie utrudnione wczesną wiosną. Topnienie śniegów, wezbranie nawet niewielkich rzek i strumieni, podtopienia właściwie uniemożliwiałyby przy ówczesnym stanie technicznym i drogowym podjęcie akcji militarnej. Współcześni doskonale o tym wiedzieli. Stąd też prawdopodobnie późnozimowy atak - był to czas idealny na czatę. Zapewniał on niezłe (przede wszystkim stabilne) warunki komunikacyjne, jednak wobec zbliżającej się wiosny raczej uniemożliwiał stronie zaatakowanej podjęcie kontrofensywy.

Jeżeli przyjmiemy założenie, że w 1579 r. w sposób skoordynowany działały trzy pułki, pojawia się pytanie, kto i w jakich okolicznościach zdobył zamek Kierepeć (Kirempe)? To bowiem pułk skrzydła prawego zmierzał do tego punktu. Dotychczas analizowane źródła jednoznacznie dają laur zwycięzcy „Piorunowi”. Kampania 1579 r., uwieńczona zdobyciem Kierepeci, została wykorzystana w propagandzie domu Radziwiłłowskiego ${ }^{60}$. O osobistym zdobyciu zamku przez Krzysztofa Radziwiłła pisał m.in. Jan Kochanowski w poemacie Jezda do Moskwy, wydanym w $1583 \mathrm{r}^{61}$ :

${ }^{57}$ Rajmund Przybylak, Gabriel Wójcik, Kazimierz Marciniak, Waldemar ChorążyCZewski, Wiesław Nowosad, Piotr Oliński, Krzysztof Syta, Zmienność warunków termiczno-opadowych w Polsce w okresie 1501-1840 w świetle danych historycznych, Przegląd Geograficzny, t. 76: 2004, z. 1, s. 18-20.

${ }^{58} \mathrm{https}$ ://ru.wikipedia.org/wiki/\%D0\%9A\%D0\%BB\%D0\%B8\%D0\%BC\%D0\%B0\% D1\%82_\%D0\%A2\%D0\%B0\%D1\%80\%D1\%82\%D1\%83 (dostęp z dnia 9 VII 2017).

${ }^{59}$ Svetlana Jevrejeva, Severity of winter seasons in the northern Baltic Sea between 1529 and 1990: reconstruction and analysis, Climate Research, vol. 17: 2001, s. 55-62.

${ }^{60}$ Należy jednak pamiętać o pojawiającym się w utworach „szumie informacyjnym” i o odnotowaniu rozmijających się z prawdą historyczną wydarzeń: Roman KRZYwY, „Chcesz być groźnym, a uciekasz...”. Nad komentarzem do epinikionów moskiewskich Jana Kochanowskiego, Pamiętnik Literacki, t. 104: 2013, z. 3, s. 185-193.

${ }^{61}$ Zob. Stanisław Łeмpicki, Wiek złoty i czasy romantyzmu w Polsce, Warszawa 1992, s. $478-479,491$. 


$$
\text { „[...] takim cię Inflanty }
$$

W tym czasie oglądały i moskiewskie kąty,

Gdzieś Derptowi w nos kurzył, Kierepeć wywrócił,

Liczbę nieprzeliczoną wsi w popiół obrócił, Więźniów zacnych nawiązał, niesłychaną plonu Moc wypędził, sam cało wrócił się do domu"62.

Dokładnie opisuje triumf „Pioruna” Andrzej Rymsza w napisanej w 1585 r. Dziesięciorocznej powieści wojennych spraw:

„Mało na tym, że Moskwę aż k Derptu prowadził, Jeszcze ku kierepecki zamek barzo wadził. Zamek dobrze obronny i ludem, i strzelbą, Siła rzekło, iż tego muru nie dobędą, Bo strzelby znaku $\mathrm{z}$ sobą nie nabrał do tego. Mężne serce radziło przedsięwzięciu jego, Aby pierwej doświadczył męstwa derpetskiego, Potym łacno sprobować i kierepetskiego.

Wiedział bowiem, iż tam lud zawżdy bywał świeży, Żywność także wszech zamkow tam lifflanskich leży"63.

Droga ciagnienia Je[g]o M[iło]ści do Inflant potwierdza opis Andrzeja Rymszy. Nagle 28 lutego zwinięto obóz spod Dorpatu i pułk skierował w drogę na Kierepeć. Po trzech dniach książę dotarł do zamku (dzienna szybkość ciągnienia ok. 23,3 km). Decyzja ta, niezaplanowana w itinerarium, musiała być wynikiem wiadomości otrzymanych od pułku prawego skrzydła. Według A. Rymszy brak silnych dział oblężniczych skłonił Rosjan do obrony zamku. Radziwiłł postanowił obiekt wziąć szturmem i w tym celu skłonił jazdę do zejścia z koni i podjęcia szturmu, który zakończył się sukcesem. Autor mimochodem jednak odnotowuje, że wśród oblegających oprócz Litwinów byli również Niemcy (Kurlandczycy?):

„Niosą łupy bogate jak Niemcy tak naszy, Jeden dziesięć Moskalow samym wzrokiem straszy.

Potym wiodą wojewod w postawie pokornej, Już im nie stało fukow ani mowy górnej. Hetman, pan miłosierny, przyjął ich do siebie" ${ }^{64}$.

${ }^{62}$ Jan Kochanowski, Dzieła polskie, wstępem i przypisami opatrzył Julian KrzyżanowSKI, t. 3, Warszawa 1953, s. 160.

${ }^{63}$ A. Rymsza, op.cit., s. 150-151, w. 159-168.

${ }^{64}$ Ibid., s. 151-152, w. 193-197. 
Dom Radziwiłłowski nie tylko propagował triumf „Pioruna” z 1579 r. w utworach poetyckich, został także zamówiony obraz, który został odrysowany w drugiej połowie XVIII stulecia na zamówienie Stanisława Augusta Poniatowskiego (zob. il. 3) ${ }^{65}$. Zawiera on wierszowany podpis, który podaję w transkrypcji i tłumaczeniu wykonanym przez Grzegorza Franczaka ${ }^{66}$.

„Krzysztof Radziwiłł hetman polny dorpacką krainę Krwawym bojem zdobywa i ogniem całą pustoszy:

Ucieczką salwuje się Moskal, pada twierdza Kierepeć, $\mathrm{Z}$ nią zaś wojenne machiny wpadają w ręce i łupy.

Stefana Wysołowcowa w kajdany zakuto, z nim razem

Ostalca też Ominowa, dwóch wojewodów moskiewskich.

A gdy kraj cały splądrował aż do samego Pskowa,

Do króla Stefana do Wilna wrócił zwycięski w tryumfie"67.

Powyższy podpis zbieżny jest $\mathrm{z}$ informacjami podanymi przez A. Rymszę, choć w sposób bezpośredni nie wiązano tu upadku zamku z osobą K. Radziwiłła. Odnotowano zdobycie zamku i pojmanie dwóch wojewodów rosyjskich, a także złupienie ogromnych obszarów w okolicy Dorpatu oraz Kierepeci aż po sam Psków ${ }^{68}$. Oczywiście ta ostatnia informacja jest przesadzona. Zdobyty zamek był oddalony w linii prostej od rosyjskiego miasta o $80 \mathrm{~km}^{69}$. Biorąc pod uwagę tempo marszruty, jednodniowa czata nie przekroczyłaby pewnie odległości $25 \mathrm{~km}^{70}$.

${ }^{65}$ M. JANICKI, op.cit., s. 212-221.

${ }^{66}$ Por. T. Żebrawski, op.cit., s. 53, nr 8.

${ }^{67}$ „Christophorus Radivil Campi Dux caede cruenta // Derpato adjunctos igneque vastat agros: // Diffugiunt Moschi capiturque arx firma Kerepet, // Machinae et insignes mu $<\mathrm{l}>$ taque praeda simul. // Vincla Palatinus Stephanus Visoslauscius atque // Ostalec Ominow tum subiere duo. // Plescoviam usque tenus populatus et omnia Vilnam // Ad Stephanum regem victor ovansque redit” (Muzeum Wojska Polskiego w Warszawie, nr inw. 16594 A*).

${ }^{68}$ Zdobywając Kierepeć, zabito ponad 60 osób, w tym starostę - Iwana Kropotowa. Do niewoli dostał się wojewoda Stefan Wysołowcow z żoną, dziećmi i 16 sługami oraz prowadzący żywność do Inflant Ostalec Michajłowicz Omianow z żoną, bratem, dziećmi i 17 sługami. РНБ, Ф. 971, Авт. 152, № 21, k. 58-58v.

${ }^{69}$ Dariusz Kupisz (op.cit., s. 98) i Piotr Łabędź (op.cit., s. 37) oceniają odległość obu obiektów na $60 \mathrm{~km}$.

${ }^{70}$ Spod Dorpatu wysłane były natomiast dwie odległe czaty. Jedna dotarła pod granicę rozdzielającą Inflanty z Carstwem Moskiewskim. Prawdopodobnie więc zakończyła swoją marszrutę nad jeziorem Czudzkim i Pskowskim. Druga czata tatarska przemierzyła rzekomo aż 10 mil. Jednak i ta wyprawa nie mogła dotrzeć pod Psków oddalony od Dorpatu o 138 km. РНБ, Ф. 971, Авт. 321/1, № 21, k. 57-57v. 
Rysunek przedstawia podpalenie zdobytego zamek Kierepeć (il. 3) ${ }^{71}$. Samo wydarzenie w poetyckiej formie przedstawił Franciszek Gradowski w Hodoeporicon Moschicum - „Tu Ceropecion flammis crepitantibus amplum // Incendens, Stygias tot millia multa sub umbras // Misisti, mediis victor generosus in armis"72. Decyzja K. Radziwiłła o zniszczeniu umocnienia wydaje się słuszna. Utrzymanie zamku wydawało się niemożliwe, z perspektywy rosyjskiej była to ważna twierdza stanowiąca przedsionek do Pskowa od strony Inflant, a oddziały litewskie były zbyt słabe, by bronić tak wysunięty punkt oporu ${ }^{73}$.

Uważna analiza rysunku ukazuje jednak zaskakujący element. Krzysztof Radziwiłł „Piorun” triumfalnie zbliża się do Kierepeci. Jednocześnie ukazany jest ostrzał umocnienia i obrona ogarniętego pożarem zamku. Sądzę, że mamy do czynienia z przedstawieniem symultanicznym ukazującym zarówno zdobycie zamku, jak i triumfalny wjazd Radziwiłła. Jego osoba przedstawiona jest w formie portretu konnego - wódz jest w zbroi, trzyma regiment i dosiada galopującego, wspiętego do skoku konia ${ }^{74}$. Zbliżające się oddziały jazdy mają chorągiew z orłem z rozpostartymi skrzydłami (prawdopodobnie był to czarny orzeł, który został Radziwiłłom nadany wraz z tytułem książęcym przez Karola $\mathrm{V}$ w $1547 \mathrm{r}^{75}$ ), za hetmanem jedzie buńczuczny $\mathrm{z}$ proporcem lub znakiem hetmańskim ${ }^{76}$. Witają go oddziały piesze $-\mathrm{z}$ ubioru wynika, że landsknechci oraz drabi autoramentu narodowego. Żołnierze tworzą szpaler, unosząc arkebuzy i oddając salwę honorową. Przy oddziale stoi chorąży ze sztandarem i muzyk wybijający rytm na bębnie. Na drugim tle widoczni są jeźdźcy palący okoliczne zabudowania oraz uciekający ludzie ${ }^{77}$.

${ }^{71}$ J. Zamoyski do J. Radziwiłła, Wilno 1 IV 1579 r., [in:] Archiwum Jana Zamoyskiego, t. 1, s. 307; R. Heidenstein, Dzieje Polski, t. 1, s. 303; R. Heidenstein, De Bello Moscovitico, s. 38.

${ }^{72}$ Franciszek Gradowski, Hodoeporicon Moschicum, Wilno 1582, w. 765-767: „Ty rozległy Kierepeć zapalając hucznym płomieniem, tyle tysięcy ludzi posłałeś do stygijskich cieniów, sam świetny zwycięzca stojąc w ogniu walk"; S. ŁEMPICKI, op.cit., s. 491. Por. Franciszek GradowsKI, Hodoeporicon Moschicum. Wyprawa moskiewska, wyd. Bartłomiej Czarski, tłum. Bartłomiej Czarski, Ariadna Masıowska-Nowak, Warszawa 2011, s. 72-73.

${ }^{73}$ Rosjanie prowadząc pertraktacje pod koniec 1581 i na początku 1582 r., starali się wywalczyć (bez powodzenia) ten zamek, który jako jedyny przypadłby im w ziemi inflanckiej. Zob. Posłowie polscy do J. Zamoyskiego, Jam Zapolski 23 XII 1581 r., [in:] Archiwum Jana Zamoyskiego, t. 2, s. 156-157; Posłowie polscy do J. Zamoyskiego, Jam Zapolski 25 XII 1581 r., [in:] ibid., s. 167.

${ }^{74}$ Mieczysław Morka, Polski nowożytny portret konny i jego europejska geneza, Wrocław-Warszawa-Kraków-Gdańsk-Łódź 1986. O wizerunkach konnych magnaterii zob. ibid., s. $165-176$.

${ }^{75}$ Sławomir Górzyński, Jolanta Grala, Włodzimierz Piwkowski, Violetta Urbaniak, Teresa ZielińsKA, Radziwiłłowie herbu Trąby, Warszawa 1996, s. 46-47.

${ }^{76}$ Karol ŁopAтескI, Znak hetmański: geneza, funkcje, symbolika, Studia i Materiały do Historii Wojskowości, t. 42: 2006, s. 59-93.

77 O skali zniszczeń świadczą dwa dokumenty. 


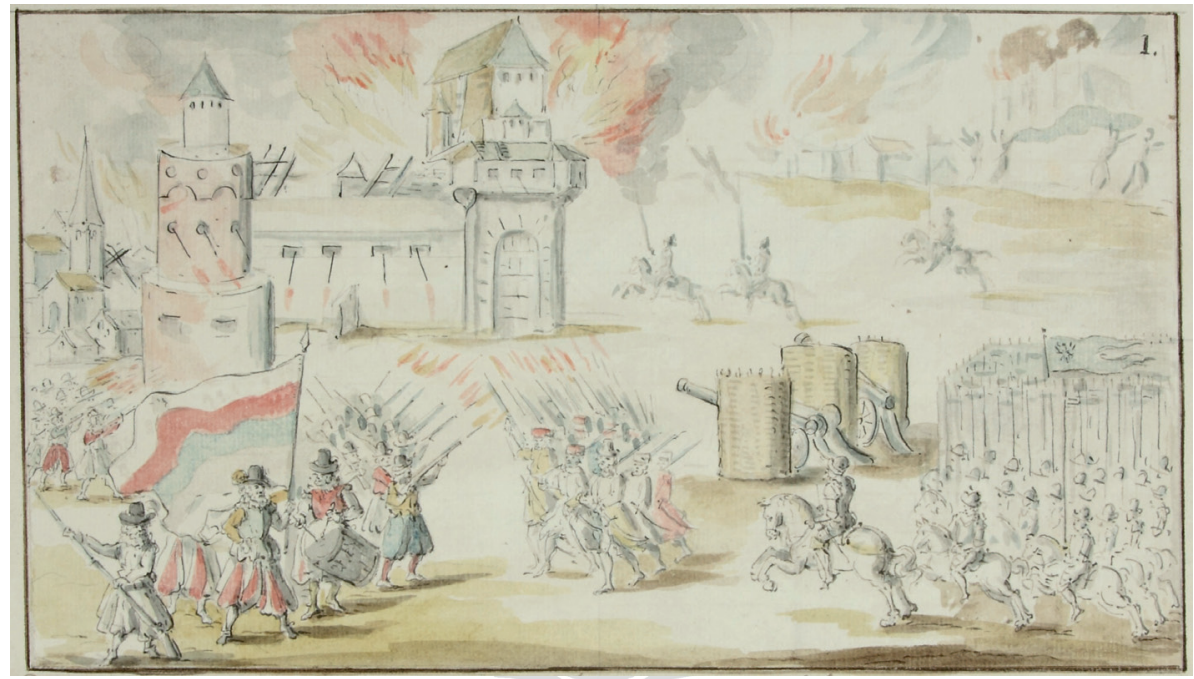

Il. 3. Zniszczenie zamku Kierepeć ${ }^{78}$,

Muzeum Wojska Polskiego w Warszawie, nr inw. 16594 A $^{*}$

Samo źródło ikonograficzne nie jest jednoznaczne i nie jest jeszcze mocnym dowodem. Natomiast inflanckie źródła pisane informują, że zamek Kierepeć w 1579 r. nie został zdobyty przez Krzysztofa Radziwiłła. Zwycięstwo przypisano oberstowi (pułkownikowi) Jürgenowi Buttlerowi, który wyruszył spod Rygi i - kierując się na Dorpat - zdobył Kierepeć, gdzie pobrał jeńców i spalił zabudowę do gołej ziemi. Tak sytuację tę opisuje Balthasar Russow, szesnastowieczny kronikarz inflancki zamieszkujący w Rewlu. W opisie zda-

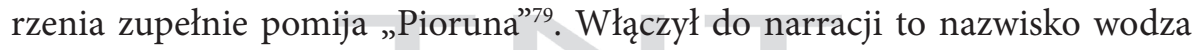

${ }^{78}$ Niestety nie posiadamy planów lub widoku zamku sprzed zniszczenia, a jedynie te pochodzące z czasów późniejszej odbudowy, przede wszystkim wykonanej przez Szwedów. Tym samym układ zamku mógł się różnić, z pewnością jednak powinien zachować się ślad po potężnej, wysuniętej przed lico muru bastei. Zarówno dostępne siedemnastowieczne plany oraz rysunek ruin zamku z 1801 r. nie pozostawiają wątpliwości co do poprawności identyfikacji zamku przedstawionego na il. 3. Zob. Krigsarkivet, 0406 (Utländska stads- och fästningsplaner 1550-1989), 28 (Östersjöprovinserna), 20 (Kiriumpä), nr 2; Johann Christoph BRoTZE, Sammlung verschiedner Liefländischer Monumente, Latvijas Akadēmiskās bibliotēkas Johana Kristofa Broces kolekcija, t. IX, k. 12v.

${ }^{79}$ Balthasar Rüssow, Livländische Chronik, Aus dem Plattdeutschen übertragen u. mit kurzen Anmerkungen versehen durch Eduard PABST, Reval 1845, s. 272: „Kiriempe verbrannt, 1579. Auf dasselbige Mal ist Jürgen Butler auch mit den Curischen und Stiftischen von Riga in’s Stift Dörpte gefallen und hat das Häuslein Kiriempe gestürmt, etliche Russen darauf erschlagen und dasselbige Haus in den Grund verbrannt"; idem, Chronica. Der Provintz Lyfflandt, darinnne vermeldet werdt [...], [b.m.w.] 1584, s. 117; Friedrich Georg von FircKs, Ueber den Ursprung des Adels in den Ostsee-Provinzen Russlands und das den alten Rittergeschlechtern daselbst gebührende Prädicat Freiherr, Mitau-Leipzig 1843, s. 148; A. SERAPHim, op.cit., s. 30-31; Constantin Metтig, Baltische Städte: Skizzen aus der livländischen Geschichte, Riga 1901, s. 9. 
Konstanty Górski, co jednak w polskiej historiografii się nie przyjęło i popadło w zapomnienie ${ }^{80}$.

Szerzej wydarzenie to opisuje siedemnastowieczny inflancki (szwedzki) kronikarz Thomasa Hiärne (1638-1678). Według niego Krzysztof Radziwiłł wyruszył spod Wenden, prowadząc 1000 polskiej, litewskiej i tatarskiej jazdy, a dodatkowo 1000 jazdy inflanckiej i kurlandzkiej pod Dorpat. Następnie odnotowano, że dowódcą zgrupowania, które zdobyło Kirempe, a następnie spaliło zamek, był kurlandzki oberst Jürgen Buttler ${ }^{81}$. Niekiedy podaje się również, że to Magnus Inflancki (1540-1583) zdobył Kirempe - błąd wynika z faktu, że opanował on ten zamek w 1581 r., o czym pisze Dionysius Fabricius ${ }^{82}$.

Oczywiście inflancko-kurlandzki wysiłek zbrojny podany przez Th. Hiärne jest nieprawdopodobny. Zwracam jednak uwagę, że oszacowanie całości sił biorących w wyprawie na 2000 osób jest wiarygodne, ponadto liczebność pułku głównego Krzysztofa Radziwiłła (1000) jest zbieżna z informacją podaną przez Andrzeja Rymszę. Konsekwentnie źródła i opracowania niemieckojęzyczne wskazują na pułkownika księcia kurlandzkiego Jürgena Buttlera jako na zdobywcę zamku Kierepeć. Źródła ukazują wyprawę wojskową, która wyruszyła spod Rygi (Krzysztof Radziwiłł przebywał w Dźwinoujściu) i miała dotrzeć aż pod Dorpat. Zestawiając te dane z itinerarium, uważam, że rzeczywiście podczas wyprawy wydzielone zostały trzy pułki. W zasadzie pułk lewy i centralny można traktować jako jednolitą siłę, gdyż ich marszruta była równoległa i dowództwo sprawował tam Krzysztof Radziwiłł „Piorun”. Natomiast pułk prawego skrzydła był dowodzony przez obersta kurlandzkiego Jürgena Buttlera i zgodnie z założeniem dotarł on aż pod Kierepeć.

Jak został zdobyty ten zamek - nie mam pewności. Są dwie prawdopodobne, przy czym sprzeczne relacje. Kierepeć mógł zdobyć pułk Buttlera, ale również prawdopodobne jest, że jedynie rozpoczął on oblężenie, a następnie wysłano do K. Radziwiłła prośbę o pomoc. Nieprzewidziany w itinerarium odcinek Dorpat-Kierepeć książę mógł przebyć także na wieść o zdobyciu zamku i konieczności podjęcia decyzji, co z nim zrobić. To rozwiązanie wydaje mi się bardziej prawdopodobne, choć bardziej spektakularną i romantyczną narrację - przemowę Radziwiłła, spieszenie jazdy i szturm na zamek - przedstawił Andrzej Rymsza:

${ }^{80}$ Konstanty Górski, Pierwsza wojna Rzeczypospolitej z Wielkiem Księztwem Moskiewskiem za Batorego, Biblioteka Warszawska, t. 4: 1892, s. 108.

${ }^{81}$ Thomas Hï̈Rn, Ehst-, Lyf- und Lettlaendische Geschichte, hrsg. Carl Eduard von NAPIERSky, Riga-Dorpat-Leipzig 1835, s. 323. Zob. K. H. von Busse, op.cit., s. 136.

${ }^{82}$ Dionysius Fabricius, Livoniae Historiae Compendiosa Series, cur. Gustav Bergmann, [in:] Drey kleine Schriften über die Geschichte Livland's, Riga 1857, s. 115; Andres AdAmson, Hertsog Magnus: 1540-1583: tema elu ja aeg, [Tallinn] 2005, s. 175. 
„Kazał swemu rycerstwu zsiadać z kopijami,

Mowiąc: «A ja sam zaraz tuż pojdę przed wami,

Pojdę przy was cnych ludziech, zdrowia nie żałując

Pojdę, wam te potrawy wiernie kredencując».

Wnet wsze zacne rycerstwo hetmanowi swemu

Dzięki dawszy, pośpieszno szli ku zamku temu

Mężnym sercem, aż krzyk ich niebo usłyszało;

Echo milczeć musiała, głosu jej nie stało" ${ }^{83}$.

Być może odnalezione w przyszłości źródła pozwolą jednoznacznie rozstrzygnąć ten problem. Bez wątpienia zdobycie zamku musiało się wiązać ze spieszeniem jazdy, gdyż posiadanej piechoty było zdecydowanie zbyt mało ${ }^{84}$.

Powyższa analiza wskazuje, że do oceny działań zbrojnych (w znaczeniu strategicznym i operacyjnym) z epoki nowożytnej niezbędne jest szczegółowe uwzględnienie czasu i przestrzeni. Ustalenia badaczy dotyczące dziennego tempa marszu, subiektywnej odległości mili podczas poszczególnych działań militarnych, a także wzajemna konfrontacja danych umożliwiają osiągnięcie dodatkowej wiedzy i oceny prowadzonych kampanii. Należy również uwzględnić czas wyprawy i zestawić go z właściwościami klimatycznymi obszaru, na którym działa armia, przy czym niezbędne wydaje się wykorzystanie badań nad zmianami klimatu i tzw. małą epoką lodowcową ${ }^{85}$.

1. Na początku 1579 r. Krzysztof Radziwiłł „Piorun” na bazie koncepcji Andrzeja Sapiehy zaprojektował wyprawę z Kiesi pod Dorpat. Nie był to jednak projekt skopiowany, lecz całkowicie nowy i w mojej ocenie nowatorski pomysł. Wyznaczono wówczas trzy trasy przemarszu. Dwie północne (trasa lewa i centralna) biegły obok siebie, trzecia (trasa prawa) miała zupełnie odmienną marszrutę, zagłębiając się w ziemie rosyjskie od zaplecza (zob. il. 1). Według mnie projekt podziału armii na trzy pułki i skoordynowania działań za pomo-

${ }^{83}$ A. Rymsza, op.cit., s. 151, w. 181-188.

${ }^{84}$ Husaria powinna w tym czasie być już uzbrojona w broń palną. Przykładowo Mikołaj Mielecki miał w Dziśnie w 1579 r. uszykować wojska „y tak ieździe iako piechocie strzlbe reczna wypuścić kazał, bo kromia kopijey, szable, y koncerza, każdy iezdny miał rusznice przy koniu", zob. M. BIELSKI, op.cit., s. 761.

${ }^{85}$ Zob. Ulf Büntgen, Tomáš Kyncl, Christian Ginzler, David S. JACKs, Jan Esper, Willy Tegel, Karl-Uwe Heussner, Josef Kyncl, Filling the Eastern European gap in millennium-long temperature reconstructions, Proceedings of the National Academy of Science of the United States, vol. 110: 2013, no. 5, s. 1773-1778 (oraz dołączony aneks); John Haldon, Lee MordechaI, Timothy P. Newfield, Arlen F. Chase, Adam Izdebski, Piotr Guzowski, Inga Labuhn, Neil ROBERTs, History meets palaeoscience: Consilience and collaboration in studying past societal responses to environmental change, ibid., vol. 115: 2017, https://doi.org/10.1073/pnas.1716912115 (dostęp z 19 III 2018 r.). 
cą itinerarium został zrealizowany. Znamy dokładną marszrutę Krzysztofa Radziwiłła, która w 90\% pokrywa się z drogą środkową. Kronikarze inflanccy wskazują obersta kurlandzkiego Jürgena Buttlera jako zdobywcę zamku Kierepeć, co wydaje się potwierdzać zachowany rysunek zajęcia zamku. Prawdopodobnie to on był dowódcą pułku lewego. Niestety nie jestem w stanie zweryfikować, czy w rzeczywistości lewy pułk został wyodrębniony i kto dowodził pułkiem prawym.

2. Analiza wykonanego przez Krzysztofa Radziwiłła itinerarium z 1579 r. wskazuje, że odnotowane mile należy przeliczać na ok. $8 \mathrm{~km}$. Wykonana w tym samym roku mapa Połocczyzny Stanisława Pachołowieckiego szacuje milę na zaledwie $5 \mathrm{~km}$. Różnica mogła wynikać z różnych jednostek (mila wielka i mała). Bardziej prawdopodobne jest przyjęcie założenia, że mila stanowiła w tym czasie subiektywną jednostkę odległości uzależnioną od jakości dróg. W takim założeniu fatalne drogi na Połocczyźnie (a w zasadzie ich brak) przekładały się na ocenę długości mili. Tymczasem drogi inflanckie musiały być dobre, miejscami bardzo dobre. Warto dodać, że późna zima zapewniała względnie najlepsze warunki komunikacji lądowej (ubity śnieg, wyznaczone szlaki - z uwzględnieniem średniej temperatury o $2^{\circ} \mathrm{C}$ niższej niż obecnie). Za nieprzypadkowy uważam więc czas wyprawy (16 lutego - 6 marca), który był idealny na łupieżczy atak. Z uwagi na zbliżające się roztopy podjęcie przez nieprzyjaciela kontrofensywy było właściwie niemożliwe. Stąd bezpieczny powrót pod Kieś i brak oddziałów moskiewskich wysłanych spod Dorpatu.

3. Średnia prędkość dzienna wyprawy Kieś-Dorpat-Kieś wynosiła 21,55 km, co odpowiadało 2,7 mili (traktowanej jako $8 \mathrm{~km}$ ). Z pewnością nie były to pułki poruszające się komunikiem, a ofensywa nie była „piorunująca”. Całość przebiegła jednak sprawnie. Niestety badań nad tempem marszu armii brakuje, wiadomo jednak, że wielkie armie batoriańskie z lat 1579-1582 poruszały się wolniej ze średnią prędkością $14 \mathrm{~km}$. Wojska te musiały się jednak przedzierać po bez porównania trudniejszych szlakach niż w Inflantach. Niewątpliwie dla badań wojskowych, politycznych i gospodarczych szybkość przemieszczania się, w tym oddziałów wojskowych, stanowi jeden z głównych postulatów badawczych. Współcześni oceniali, że wojsko rzymskie poruszało się z prędkością dzienną $29600 \mathrm{~m}^{86}$, ale należy pamiętać, że przemieszczanie odbywało się po rzymskich drogach.

4. Analiza kartograficzna wskazuje, że podczas prac nad itinerariami prawdopodobnie wykorzystywano mapy. Nie mogły to być jednak drukowane źródła kartograficzne, lecz rękopiśmienne. Oczywiście nadal najważniejsze było

${ }^{86}$ Marcin BIELSKI, Sprawa Rycerska wedtug postępku y zachowania starego obyczaju Rzymskiego, Greckiego, Macedońskiego y innych Narodow pierwszegi y ninieyszego Wieku tak Pogańska iako y Krześciiańska z rozmaitych Ksiagg wypisana ku czytaniu y Nauce Ludidziom Rycerskim pożyteczna, Kraków 1569, k. 6v, 10. 
doświadczenie i wiedza osób znających tę prowincję, ale na potrzeby wizualizacji przestrzennej niezbędne wydaje się wykorzystanie źródeł kartograficznych.

5. Zwrócić należy również uwagę na wysiłek żołnierzy i koni, czyli długość pokonanej drogi. W świetle itineratium szlak lewy wynosił $184,96 \mathrm{~km}$, centralny 178,63 km, natomiast prawy był znacznie dłuższy i liczył 381,33 km. Jeżeli jednak uwzględnimy, że dwa pierwsze pułki spod Dorpatu udały się pod Kierepeć, pułk lewy zaś zakończył swój pochód zgodnie z planem - wówczas otrzymujemy odpowiednio: 254,81 km, 248,48 km i 311,48 km. Żołnierze litewscy przeciętnie w czasie kampanii zimowej 1579 r. przejechali lub przeszli ponad $500 \mathrm{~km}$. Wojsko nie było jednak zmęczone, a konie nie były poranione i wyczerpane przebytą drogą, gdyż zamiast rozlokować się w okolicach Dźwiny, żołnierze samowolnie udali się do Wilna w celu uzyskania należnej im wypłaty. Oznaczało to pokonanie kolejnych $300 \mathrm{~km}^{87}$. Stan dróg, warunki klimatyczne, jak i w ogólności sama trasa musiały być dobre dla żołnierzy i czata nie doprowadziła do znacznego pogorszenia wartości bojowej oddziałów ${ }^{88}$.

7. Cała wyprawa liczyła: ok. 2200 żołnierzy jazdy, z pewnością kilka oddziałów piechoty (ok. 400 drabów) oraz działa, jednak bez ciężkiej artylerii, a także stosunkowo liczny tabór (szacuję go na 100 wozów). Skala zniszczeń, wielkość łupów oraz sukcesy militarne wynikały przede wszystkim z wydzielenia z armii trzech pułków. Działanie takie dezorientowało nieprzyjaciela i nie pozwalało mu podjąć skutecznej obrony. Oceniając wyprawę zimową $1579 \mathrm{r}$. do Inflant, uznaję ją jako najlepszy przykład sztuki manewrowej w XVI stuleciu.

Nadesłany 20 I 2018

Nadesłany po poprawkach recenzyjnych 15 III 2018 Zaakceptowany 25 III 2018

Dr hab. Karol Łopatecki

Instytut Historii i Nauk Politycznych

Uniwersytet w Białymstoku

e-mail: karol_lopatecki@wp.pl

ORCID ID: 0000-0002-7921-9421

${ }^{87}$ P. ŁABĘDŹ, op.cit., s. 37.

${ }^{88}$ Dla porównania czata wysłana spod Mitawy w okolice Kokenhausen pod koniec listopada 1621 r., w wyniku złej drogi, "grudą pochromione” zostało ok. 70\% wszystkich koni, zob. Rejestr wojska zdatnego do boju z pułku Aleksandra Gosiewskiego, [in:] Jan Kunowski, Ekspedycyja inflantska 1621 roku, oprac. Wojciech WALCZAK, Karol ŁOPATECKI, Białystok 2007, s. 178. 


\section{The Military Expedition of Krzysztof RadziwiŁ£ „Perkūnas” TO Livonia IN THE Winter OF 1579}

\section{Summary}

Key words: itinerarium, military cartography, Kierepeć [Kirempe], Dorpat [Tartu], Livonia in the $15^{\text {th }}$ century

The article presents the Lithuanian expedition carried out in Livonia in the winter of 1579. On the basis of the itinerary [itinerarium] and iconographic and written sources it has been established that three regiments were to act in a coordinated manner to conduct the military action against the Russian Empire. All the three regiments were to set off from Kieś [Wenden] and through different ways reach Dorpat [Tartu] occupied by the Russians. The whole expedition included about 200 cavalry soldiers and about 400 common infantry soldiers [Polish: drab] along with several light artillery and a numerous lager. Owing to the activities undertaken by the three regiments, destructions were much more extensive, more loot was acquired and military successes were more significant - the castle of Kierepeć was conquered. The activity of three separate regiments confused the enemy and prevented them from undertaking the effective defence. The expedition was carried out from 16 February to 6 March, which also affected its outcome. The late winter provided the best conditions for the land communication, while the upcoming thaw made it impossible for the enemy to launch the counter-defence. It resulted in the safe return to Kies and a lack of Moscovite units sent from Dorpat. To my way of thinking, the winter expedition of 1579 to Livonia was the best example of the manoeuvre art of the Polish-Lithuanian army in the $16^{\text {th }}$ century.

The routes of two regiments (the left one and the central one) ran close to each other, while the third one (the right one) had a totally different route entering the Russian lands from the back. The right regiment was commanded by the Oberst [Colonel] of Courland Jürgen Buttler, who conquered the castle of Kierepeć [Kirempe]. The main unit was commanded by Krzysztof Radziwiłł nicknamed "Perkūnas", who plundered the vicinities of Dorpat. The analysis of the itinerary of 1579 prepared by Krzysztof Radziwiłł indicates that the mile recorded there corresponded to 8 kilometres. The average daily velocity of the expedition Kieś-Dorpat-Kieć amounted to 21.55 $\mathrm{km}$, which corresponded to 2.7 miles. During the expedition the regiments covered from 250 to $310 \mathrm{~km}$, which along with the return journey amounted to $500 \mathrm{~km}$. 


\section{Der Feldzug von Krzysztof RadziwiŁe „Piorun“ \\ IN LIVLAND IM WINTER 1579}

\section{Zusammenfassung}

Schlüsselwörter: itinerarium, Militärkartografie, Kirempe, Dorpat, Livland im 16. Jahrhundert

Der Artikel handelt vom litauischen Feldzug in Livland im Winter 1579. Auf der Grundlage eines wiederaufgefundenen itinerarium sowie von ikonografischen und schriftlichen Quellen konnte ermittelt werden, dass damals drei Regimenter gebildet wurden, die in koordinierter Weise eine Militäraktion gegen das russische Zarenreich durchführen sollten. Alle sollten aus Wenden aufbrechen und auf verschiedenen Wegen in das von den Russen besetzte Dorpat gelangen. Am gesamten Feldzug nahmen etwa 2000 berittene Soldaten und etwa 400 Schützen teil, dazu kamen einige leichte Geschütze und ein verhältnismäßig umfangreicher Tross. Durch die Operationen von drei Regimentern wurde der Bereich der angerichteten Zerstörungen erweitert, die Beute vergrößerte sich und man errang militärische Erfolge, vor allem durch die Eroberung der Burg Kirempe. Die Operationen von drei getrennten Gruppen verwirrten den Gegner und machten ihm eine wirksame Verteidigung unmöglich. Von Bedeutung war auch die Wahl des Zeitpunkts des Feldzugs (16. Februar - 6. März). Der Spätwinter ermöglichte die vergleichsweise besten Bedingungen für den Landverkehr, und das herannahende Tauwetter machte es dem Gegner unmöglich eine Gegenoffensive zu beginnen. So kam man sicher nach Wenden zurück, und es wurden keine Moskauer Einheiten in Richtung Dorpat entsandt. Der Winterfeldzug von 1579 nach Livland kann in meinen Augen als das beste Beispiel für die Bewegungskunst der polnischlitauischen Armeen im 16. Jahrhundert gelten.

Die Marschwege von zwei Regimentern (des linken und des mittleren) verliefen nebeneinander, das dritte (rechte) hatte eine ganz andere Marschroute und drang gleichsam vom Hinterland in russisches Gebiet ein. Das rechte Regiment wurde vom kurländischen Oberst Jürgen Buttler geführt und eroberte die Burg Kirempe. Die Hauptmacht führte Krzysztof Radziwiłł „Piorun“, der die Umgebung von Dorpat plünderte. Eine Analyse des von Krzysztof Radziwiłł zurückgelegten itinerarium von 1579 zeigt, dass man die verzeichneten Meilen auf etwa acht Kilometer umrechnen muss. Die mittlere Tagesgeschwindigkeit auf dem Zug Wenden - Dorpat - Wenden betrug 21,55 Kilometer, was 2,7 Meilen entsprach. Die Regimenter legten im Verlauf des Feldzugs zwischen 250 und 310 Kilometern zurück, zusammen mit dem Rückweg waren es über 500 Kilometer.

\section{Bibliografia}

Adamson, Andres. Hertsog Magnus 1540-1583: tema elu ja aeg. [Tallinn]: Argo, 2005. Alexandrowicz, Stanisław. Kartografia Wielkiego Księstwa Litewskiego od XV do połowy XVIII wieku. Warszawa: Instytut Historii Nauki PAN, Oficyna Wydawnicza Aspra-JR, 2012. 
Alexandrowicz, Stanisław. "Kartografia wojskowa Wielkiego Księstwa Litewskiego do połowy XVII wieku.” In Kartografia wojskowa krajów strefy bałtyckiej XVI-XX w., edited by Stanisław Alexandrowicz, Zbigniew Karpus, Władysław Rezmer, 11-22. Toruń: Uniwersytet Mikołaja Kopernika, 1996.

Alexandrowicz, Stanisław. "Mapa Wielkiego Księstwa Litewskiego Tomasza Makowskiego z 1613 r. tzw. „radziwiłłowska”, jako źródło do dziejów Litwy i Białorusi.” Studia Źródłoznawcze no. 10 (1965): 33-67.

Alexandrowicz, Stanisław. Rozwój kartografii Wielkiego Księstwa Litewskiego od XV do połowy XVIII wieku. Poznań: Wydawnictwo Naukowe Uniwersytetu im. Adama Mickiewicza, 1989.

Balcerek, Mariusz. Księstwo Kurlandii i Semigalii w wojnie Rzeczypospolitej ze Szwecja w latach 1600-1629. Poznań: Wydawnictwo Poznańskie, 2012.

Baltisches historisches Ortslexikon, Teil 2: Lettland (Südlivland und Kurland), eds. Heinz Feldmann, Hans von zur Mühlen. Köln-Wien: Böhlau, 1990.

Buczek, Karol. “Dorobek kartograficzny wojen Stefana Batorego”. Wiadomości Stużby Geograficznej 8/3 (1934): 3-16.

Busse, Karl Heinrich von. Herzog Magnus, König von Livland: ein fürstliches Lebensbild aus dem 16 Jahrhundert. Leipzig: Duncker \& Humblot, 1871.

Buntgen, Ulf, and Tomaš Kyncl, Christian Ginzler, David S. Jacks, Jan Esper, Willy Tegel, Karl-Uwe Heussner, Josef Kyncl. "Filling the Eastern European gap in millennium-long temperature reconstructions." Proceedings of the National Academy of Science of the United States 110/5 (2013): 1773-1778.

Čelkis, Tomas. "Stan dróg lądowych i struktura systemu połączeń w Wielkim Księstwie Litewskim w końcu XV-XVII wieku." Zapiski Historyczne 79/3 (2014): 39-61.

Czaja, Roman. "Miasta inflanckie i estońskie w XIII-XVI wieku." In Inflanty $w$ średniowieczu: władztwa zakonu krzyżackiego i biskupów, edited by Marian Biskup, 55-74. Toruń: Towarzystwo Naukowe w Toruniu, 2002.

Ferenc, Marek. Mikołaj Radziwitł „Rudy” (1515-1584). Kraków: Towarzystwo Wydawnicze „Historia Iagellonica”, 2008.

Górski, Konstanty. "Pierwsza wojna Rzeczypospolitej z Wielkiem Księztwem Moskiewskiem za Batorego.” Biblioteka Warszawska 4 (1892): 93-117.

Górzyński, Sławomir, Jolanta Grala, Włodzimierz Piwkowski, Violetta Urbaniak, and Teresa Zielińska. Radziwiłłowie herbu Trąby. Warszawa: DiG, 1996.

Haldon, John, Lee Mordechai, Timothy P. Newfield, Arien F. Chase, Adam Izdebski, Piotr Guzowski, Inga Labuhn, and Neil Roberts. "History meets palaeoscience: Consilience and collaboration in studying past societal responses to environmental change." Proceedings of the National Academy of Science of the United States. https://doi.org/10.1073/pnas.1716912115.

Herbst, Stanisław. Wojna inflancka: 1600-1602. Warszawa: Towarzystwo Naukowe Warszawskie, 1938.

Janicki, Marek. “Obraz Bitwa pod Orszą - geneza, datowanie, wzory graficzne a obraz bitwy „na Kropiwnej” i inne przedstawienia batalistyczne w wileńskim pałacu Radziwiłłów." In Bitwa pod Orsza, edited by Marek Nagielski, 173-225. Warszawa: Neriton, 2015. 
Jevrejeva, Svetlana. "Severity of winter seasons in the northern Baltic Sea between 1529 and 1990: reconstruction and analysis." Climate Research 17 (2001): 55-62.

Kolberg, Juliusz. Porównanie miar i wag teraźniejszych i dawniejszych w Królestwie Polskiem używanych z zagranicznemi, przerobił i powiększył Wilhelm Kolberg. Warszawa: druk Józefa Węckiego, 1838.

[Kopernicki, Walery]. Rzeki i jeziora. Tekst objaśniający do mapy hydrograficznej dawnej Słowiańszczyzny części północno-zachodniej. Warszawa: Skład Główny G. Gebethner i Wolff, 1883.

Korzon, Tadeusz. Dzieje wojen i wojskowości w Polsce, vol. II. Kraków: Akademia Umiejętności, 1912.

Kotarski, Henryk. "Wojsko polsko-litewskie podczas wojny inflanckiej 1576-1582. Sprawy organizacyjne. Część II." Studia i Materiały do Historii Wojskowości 17/1 (1971): 51-124.

Krzywy, Roman. “„Chcesz być groźnym, a uciekasz...”. Nad komentarzem do epinikionów moskiewskich Jana Kochanowskiego.” Pamiętnik Literacki 104/3 (2013): 185-194.

Kula, Witold. Miary i ludzie. Warszawa: Państwowe Wydawnictwo Naukowe, 1970.

Kupisz, Dariusz. Połock 1579. Warszawa: Bellona, 2003.

Lulewicz, Henryk. “Radziwiłt Krzysztof zwany Piorunem.” In Polski słownik biograficzny, vol. 30, 264-276. Wrocław: Zakład Narodowy im. Ossolińskich, 1987.

Lulewicz, Henryk. "Rymsza Andrzej h. Gozdawa." In Polski słownik biograficzny, vol. 33, 532-533. Wrocław: Zakład Narodowy im. Ossolińskich, 1991-1992.

Łabędź, Piotr. "Działalność wojskowa Krzysztofa Radziwiłła „Pioruna” w latach 1572-1579." Zapiski Historyczne 76/1 (2011): 23-40.

Łempicki, Stanisław. Wiek złoty i czasy romantyzmu $w$ Polsce. Warszawa: Wydawnictwo Naukowe PWN, 1992.

Łopatecki, Karol. “Okoliczności powstania i przydatność wojskowa Descriptio ducatus Polocensis Stanisława Pachołowieckiego.” Terminus 19/1 (2017): 75-125.

Łopatecki, Karol. “Znak hetmański: geneza, funkcje, symbolika.” Studia i Materiały do Historii Wojskowości 42 (2006): 59-93.

Łuczyński, Jarosław. "Przestrzeń Wielkiego Księstwa Litewskiego na mapie radziwiłłowskiej Tomasza Makowskiego z 1613 r. w świetle treści kartograficznej i opisowej." Zapiski Historyczne 78/1 (2013): 73-99.

Mettig, Constantin. Baltische Städte: Skizzen aus der livländischen Geschichte. Riga: Rigaer Tageblatt, 1901.

Morka, Mieczysław. Polski nowożytny portret konny i jego europejska geneza. Wrocław-Warszawa-Kraków-Gdańsk-Łódź: Zakład Narodowy im. Ossolińskich, 1986.

Niesiecki, Kasper. Herbarz Polski, vol. 3, wyd. Jan Nepomuce Bobrowicz. Lipsk: Breitkopf i Haertel, 1839.

Plewczyński, Marek. "Wkład Radziwiłłów w rozwój staropolskiej sztuki wojennej XVI w." Miscellanea Historico-Archivistica 7 (1997): 27-36.

Przybylak, Rajmund, Gabriel Wójcik, Kazimierz Marciniak, Waldemar Chorążyczewski, Wiesław Nowosad, Piotr Oliński, Krzysztof Syta. “Zmienność warunków ter- 
miczno-opadowych w Polsce w okresie 1501-1840 w świetle danych historycznych." Przegląd Geograficzny 76/1 (2004): 5-31.

Rachuba, Andrzej. "Obraz działalności publicznej nielubianego bohatera. Uwagi w związku z pracą Arkadiusza Czwołka o Lwie Sapieże." Kwartalnik Historyczny 122/2 (2015): 323-346.

Radoch, Marek. "Die littauischen Wegeberichte jako źródło wiedzy geograficznej w Zakonie Krzyżackim o ziemiach Wielkiego Księstwa Litewskiego.” In Nauki pomocnicze historii. Teoria, metody badań, dydaktyka, edited by Aleksandra Jaworska, Robert Jop, 263-271. Warszawa: wydawnictwo 2013.

Raid, Tõnu. “Raffaello Barberini teedekaart aastast 1564." TUNA 11/2 (2008): 7-20.

Rzepka, Wojciech R., and Alojzy Sajkowski. “Andrzeja Rymszy „Dziesięćroczna powieść wojennych spraw..” (1585).” In Miscellanea staropolskie, vol. 4, 133-222. Wrocław-Warszawa-Kraków-Gdańsk: Zakład Narodowy im. Ossolińskich Wydawnictwo PAN, 1972.

Seraphim, August. Die Geschichte Des Herzogtums Kurland (1561-1795). Reval: F. Kluge, 1904.

Słownik geograficzny Królestwa Polskiego i innych krajów słowiańskich, vol. 12, edited by Bronisław Chlebowski. Warszawa: Druk „WIEKU” Nowy Świat Nr 61, 1892.

Słownik geograficzny Królestwa Polskiego i innych krajów słowiańskich, vol. 1-2, edited by Filip Sulimierski, Bronisław Chlebowski, Władysław Walewski. Warszawa: Nakładem Filipa Sulimierskiego i Władysława Walewskiego, 1880-1881.

Stamm, Edward. Staropolskie miary, cz. 1: Miary długości i powierzchni. Warszawa: [s.n.] 1938.

Tuulse, Armin. Die Burgen in Estland und Lettland. Dorpat: Verlag, 1942.

Wrede, Marek. Itinerarium króla Stefana Batorego 1576-1586. Warszawa: Wydawnictwo DiG, 2010.

Wyrozumska, Bożena. Drogi w ziemi krakowskiej do końca XVI wieku. Wrocław: Zakład Narodowy im. Ossolińskich, 1970. 